\title{
Septarian carbonate concretions in the Permian Rio do Rasto Formation: Birth, growth and implications for the early diagenetic history of southwestern Gondwana succession
}

\author{
Luciano Alessandretti ${ }^{\mathrm{a}, *}$, Lucas Veríssimo Warren ${ }^{\mathrm{b}}$, Rômulo Machado ${ }^{\mathrm{a}}$, \\ Valdir Felipe Novello ${ }^{a}$, Isaac Jamil Sayeg ${ }^{a}$ \\ a Instituto de Geociências, Universidade de São Paulo, Rua do Lago, 562, Cidade Universitária, São Paulo, SP CEP 05508-080, Brazil \\ ${ }^{\mathrm{b}}$ Instituto de Geociências e Ciências Exatas, Departamento de Geologia Aplicada, Universidade Estadual Paulista, Avenida 24-A, Bela Vista, Rio Claro, SP CEP 13506-900, Brazil
}

\section{A R T I C L E I N F O}

\section{Article history:}

Received 2 April 2015

Received in revised form 14 June 2015

Accepted 15 June 2015

Available online 21 June 2015

Editor: B. Jones

\section{Keywords:}

Septarian carbonate concretions

Late Permian

Southwestern Gondwana

Paraná Basin

Rio do Rasto Formation

Serrinha Member

\begin{abstract}
A B S T R A C T
Between the Late Carboniferous and Early Triassic, the southwestern Gondwana supercontinent was characterized by the development of a huge intracratonic basin. A large confined epeiric sea and the accumulation of a transgressive-regressive sequence were formed by continuous subsidence related to tectonic effects caused by the Sanrafaelic Orogeny and the consequent generation of accommodation space. The Permian Rio do Rasto Formation documents the last progradational cycle related to the complete continentalization of this epeiric sea. The basal member of the Rio do Rasto Formation (Serrinha) is believed to have been deposited in a shallow epicontinental water body subjected to storms and influenced by episodic deltaic incursions. One of the most remarkable characteristics of the Serrinha Member is the presence of carbonate concretions hosted in mudstones and very fine sandstones. Here, we combine sedimentological and petrographic descriptions coupled with geochemical and stable carbon and oxygen isotopic data to elucidate the nature of these carbonate concretions. The nondeformed internal structure, decreasing proportion of carbonate cements relative to detrital grains toward the concretion edges, core-to-rim isotopic variations, and perhaps most importantly, the preservation of a welldeveloped cardhouse fabric support an early diagenetic origin for these structures at shallow burial depths of tens of meters. Stable isotope analyses of micritic calcite cements and calcites filling the septarian fractures reveal major negative excursions in both $\delta^{18} \mathrm{O}$ and $\delta^{13} \mathrm{C}$ values. Oxygen isotope ratios obtained for the micritic calcite cements vary between -12.1 and $-2.6 \%$. The calcite filling septarian fractures also exhibit negative values of $\delta^{18} \mathrm{O}\left(-14.2\right.$ to $-13.8 \%$ ), with an average of $-14 \%$. The $\delta^{13} \mathrm{C}$ values of micritic calcite cements range from $-5.0-0.2 \%$. The carbon isotopic data from the calcite-filling septarian fractures are also negative $(-4.4$ to $-3.3 \%$ ). The $\delta^{18} \mathrm{O}$ signatures suggest that the early diagenetic carbonate concretions precipitated in a shallow freshwater environment rather than in a marine setting. The $\delta^{13} \mathrm{C}$ values suggest that the carbon isotopes were derived from a source with slightly depleted ${ }^{13} \mathrm{C}$, supporting at least a partial organogenic contribution with weak sulfate reduction rates typical of freshwater systems. Sedimentological analysis shows that the epicontinental water body in which the Serrinha Member was deposited was constantly supplied by rivers and meteoric waters, which suggests that an enormous freshwater basin with restricted marine connections to the Panthalassa Ocean once existed.
\end{abstract}

(c) 2015 Elsevier B.V. All rights reserved.

\section{Introduction}

Carbonate concretions are typical diagenetic features commonly found in fine-grained sedimentary rocks. These concretions provide substantial information about the progressive chemical evolution of interstitial pore waters and the cementation of mineral phases during the early burial of the sediments (Irwin et al., 1977; Hudson et al., 2001; Seilacher, 2001; McBride et al., 2003, Raiswell, 2002, Mozley and

\footnotetext{
* Corresponding author at: Programa de Pós-Graduação em Recursos Minerais e Hidrogeologia Instituto de Geociências - Universidade de São Paulo.

E-mail address: luciano.geoufrgs@gmail.com (L. Alessandretti).
}

Davis, 2005; Woo and Khim, 2006; Dale et al., 2014). Although much of the geochemical (Irwin et al., 1977; Curtis et al., 1986; Wilkinson, 1993; Abdel-Wahab and McBride, 2001; Raiswell et al., 2002; Woo and Khim, 2006; Wanas, 2008; Mahboubi et al., 2010; Dale et al., 2014) and textural information (Astin, 1986; Selles-Martinez, 1996; Yemane and Kelts, 1996; Seilacher, 2001) has contributed to our increased knowledge about the genesis of these concretions, the nucleation and growth of these structures are still not fully understood. It is generally accepted that they were formed at burial depths of tens to hundreds of meters via carbonate and/or sulfate cementation as a consequence of geochemical changes in the pore waters (Irwin et al., 1977; Froelich et al., 1979; Curtis et al., 1986, Compton, 1988, Mozley 
and Burns, 1993; Dong et al., 2013). The degradation of organic matter by sulfate-reducing bacteria is related to carbonate precipitation and growth of carbonate nodules in organic-rich sediments. The interstitial pore waters in such environments lead to an increase in the carbonate alkalinity and lower the sulfate ion concentration to near zero (Compton, 1988). The concretions have been found in sediments and sedimentary rocks over a wide range of depositional environments, including marine (Abdel-Wahab and McBride, 2001; Woo and Khim, 2006; Wanas, 2008) and non-marine environments (Yemane and Kelts, 1996; Wanas, 2008; Hoareau et al., 2009). Furthermore, these depositional environments have ages ranging from the Precambrian (Goldberg et al., 2006; Dong et al., 2013) through the entire Phanerozoic (Vochten and Geys, 1974; Pirrie and Marshall, 1991; Rabassa, 2006; Woo and Khim, 2006; Wanas, 2008). The concretions are typically sub-spherical to spherical but frequently take on a variety of other shapes including disks, ellipses, continuous or discontinuous bands, grape-like aggregates, coalescent bodies and complex shapes (McBride et al., 1995; Selles-Martinez, 1996; Seilacher, 2001).

The concretions are often cut by one or more generations of fractures also known as septarian cracks/fractures. These fractures are completely or partially filled by carbonate cements and secondary minerals such as silica, phosphates and sulfates. They typically range in shape: subvertical lenses, concentric sheets, radial or crosscutting fractures. The processes involved in the formation of septarian cracking have been explained by the following: (i) shrinkage (brittle fracturing) induced by the dehydration of clay minerals or organic matter (Raiswell, 1971); (ii) compaction and overpressure of pore waters (Astin, 1986); (iii) gas generation due to bacterial decay of organic compounds (Irwin et al., 1977); and (iv) syn-depositional earthquake-induced ground motion (Pratt, 2001). Due to the post-depositional origin of the concretions, they have been used as key features for understanding the diagenetic evolution of the sedimentary rocks (Irwin et al., 1977).

The Rio do Rasto Formation is sub-divided into the lower Serrinha and upper Morro Pelado members, and their depositional environments range from offshore settings affected by storms to deltaic and aeolian systems (Warren et al., 2008). Because typical marine fossils (such as echinoderms, bryozoans and brachiopods) are lacking and sedimentological evidence refutes the action of astronomic tides (e.g., tidal bundles, mud/sand pairs, asymmetry in paleocurrents), all of the Permian succession of the Passa Dois Group is considered to have been deposited in a confined interior sea of uncertain salinity (Lavina, 1991).

The presence of Permian-aged carbonate concretions in the Paraná Basin (Fig. 1), particularly in the Rio do Rasto Formation, has been acknowledged for many years, although few studies have been published. On the basis of sedimentological and paleontological evidence (Schneider et al., 1974; Gama Jr., 1979; Rohn, 1994; Warren et al., 2008; Holz et al., 2010), it is impossible to definitively determine if these concretions were formed in a freshwater lacustrine or a marine depositional environment.

In this work, we combine field, petrographic and stable $\delta^{18} \mathrm{O}$ and $\delta^{13} \mathrm{C}$ isotopic data to elucidate the diagenetic fluid history and the genesis of the carbonate concretions and their septarian fractures in the Late Permian Serrinha Member. Despite the importance for lithification, the origin and growth pattern of these structures during early diagenesis can reveal important environmental information about the immediate stages after the sedimentary deposition.

\section{Regional geological context}

The Paraná Basin is an enormous intracratonic basin that was located in the southwestern portion of the Gondwana supercontinent during the Phanerozoic eon (Milani, 1997). Its origin and evolution has been associated with several subsidence cycles, presumably caused by litospheric flexure related to different orogeny cycles that occurred at the marginal portions of southwestern Gondwana (Milani and Ramos, 1998). This portion of the supercontinent was subjected to the successive amalgamation of several allochthonous terrains that collided against the Gondwana proto-Pacific margin (Ramos, 1984, 1986, 2008; Gohrbandt, 1992; Milani and Ramos, 1998). Ramos (1986) divided the orogenic phases into three major tectonosedimentary cycles: the Pampean (Neoproterozoic to Early Cambrian), the Famatinian (Ordovician to Devonian) and the Gondwanic (Carboniferous to Triassic). The sedimentary successions that were deposited during the major tectonic subsidence cycles consist of, from the base to the top, the following supersequences: Rio Ivaí (Ordovician-Silurian), Paraná (Devonian), Gondwana I (Carboniferous-Eotriassic), Gondwana II (Meso-Neotriassic), Gondwana III and Bauru (Neocretacic). The first three supersequences represent successions deposited under the influence of transgressive-regressive cycles related to fluctuations of the relative sea level during Paleozoic times. The remaining supersequences (Gondwana II, Gondwana III and Bauru) include continental sedimentary successions associated with the breakup of the Gondwana supercontinent, and the Cretaceous volcanic eruptions related to the Large Igneous Province of the Serra Geral Formation. Each of these supersequences encompasses a time interval of tens of millions of years and is temporally delimited by regional disconformities.

The deposition of the second-order supersequence "Gondwana I" (Pennsylvanian-Eotriassic) is related to a flexural subsidence cycle associated with the subduction of the Panthalassa oceanic lithosphere under the South Gondwana plate, and the subsequent docking of the Patagonia terrane (Ramos, 2008). Due to the lithospheric thickening and the rise of mountain chains along the southwestern Gondwana margin, large-scale marine incursions became restricted in the subsiding basin area, resulting in the formation of a large and confined body of shallow water (Milani, 1997). Between the Late Permian and the Early Triassic, this newly formed basin occupied a vast area and was characterized by the accumulation of a transgressive-regressive succession.

Lithostratigraphically, the Gondwana I supersequence is composed of the Itararé, Guatá and Passa Dois groups. The Itararé Group forms the basal part of the supersequence and consists of diamictites and other glacial-related rocks deposited during the Late Carboniferous and Early Permian on the southern hemispherical Gondwana supercontinent. After the end of the Paleozoic glaciation, a new sedimentary state was established in southern Gondwana in response to drastic climate changes and consequent sea level rise (Limarino et al., 2013), as documented in the chrono-correlated sedimentary units in South America (Fig. 11), South Africa, Namibia, Tanzania, Antarctica, India and Australia (Veevers and Powell, 1987). At the end of the Paleozoic, warm, semi-arid conditions existed in southern Gondwana, which were synchronous with an important progradational cycle. Low subsidence rates associated with a high sediment influx provided the conditions for the deposition of a second-order progradational succession. The deltaic, fluvial, lacustrine and eolian rocks of the Rio do Rasto and Piramboia formations are representative of this marine regression that culminates with the definitive continentalization of the basin during the Permian-Triassic transition (Lavina, 1991; Warren et al., 2008).

\subsection{The Rio do Rasto Formation}

The Rio do Rasto Formation (Fig. 2) outcrops along the eastern border of the Paraná Basin, mainly in the Paraná, Santa Catarina and Rio Grande do Sul states. The unit is delimited at the base and at the top by transitional contacts with the Teresina and Piramboia formations, respectively (Milani, 1997; Warren et al., 2008). Lithologically, it is characterized by an alternating 250-300-m-thick succession of sandstones, siltstones and mudstones, supposedly deposited during the Late Permian-Early Eotriassic (Schneider et al., 1974; Lavina, 1991; Warren et al., 2008). The Rio do Rasto Formation represents the upper portion of the Permo-Triassic transgressive-regressive cycle in the Paraná Basin. During this period, the limited or absent marine connection of the Paraná Basin with the Panthalassa Ocean was likely related to orogeny at the Gondwana continental margin, which led to the formation of a large 

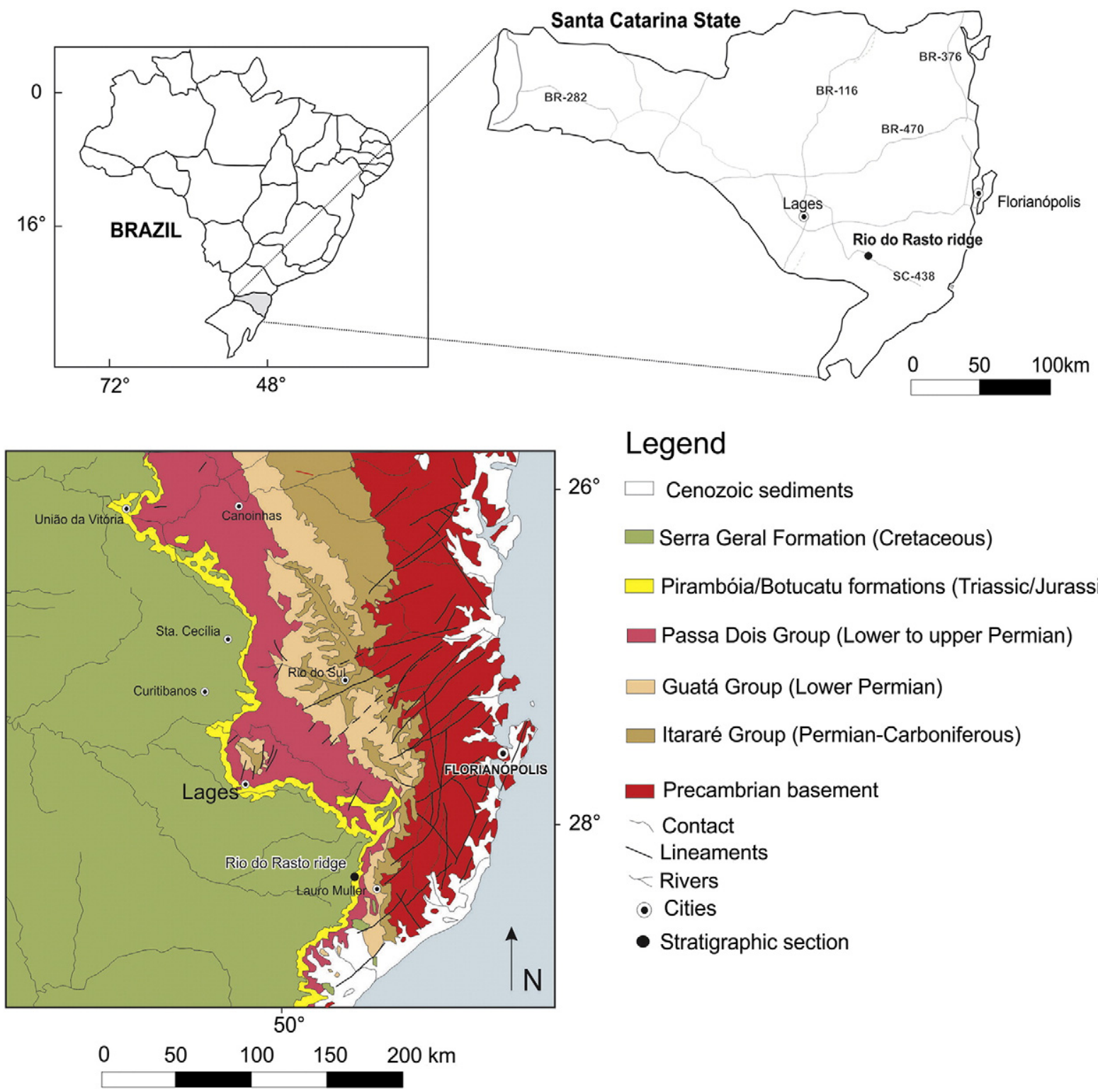

\section{Legend}

\section{Cenozoic sediments}

Serra Geral Formation (Cretaceous)

$\square$ Pirambóia/Botucatu formations (Triassic/Jurassic)

Passa Dois Group (Lower to upper Permian)

\section{Guatá Group (Lower Permian)}

Itararé Group (Permian-Carboniferous)

Precambrian basement

$28^{\circ}$

Contact

$>$ Lineaments

$\checkmark$ Rivers

- Cities

- Stratigraphic section

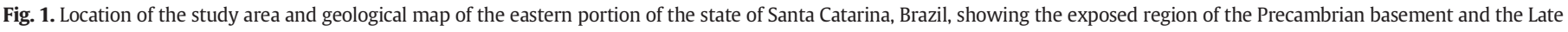
Paleozoic sedimentary rocks of the Paraná Basin.

Modified from Schobbenhaus et al. (1984).

hinterland shallow water body surrounded by cratonic Precambrian landmasses and accreted Paleozoic terranes south-southwestward.

The Rio do Rasto Formation was formally subdivided into the Serrinha (lower) and Morro Pelado (upper) members (Gordon Jr. et al., 1947). Its progradational architecture is characterized by the tendency of sandstones to increase in frequency and size to the top. The sediments of the Serrinha Member (Figs. 2, 3) are primarily characterized by the presence of swaley/hummocky, heterolithic and laminated fine sandstones interbedded with pelitic gray-colored facies, suggesting deposition in offshore conditions that was occasionally subject to storm-wave action (Rohn, 1994; Warren et al., 2008). The occurrence of architectural elements with hummocky and swaley structures reinforces the idea that episodic deposition occurred under high-energy combined flow conditions. Fossil concentrations composed of teeth, scales and fish coprolites, here classified as bone beds, also present taphonomic similarities with storm-generated deposits (Rohn, 1994). Lenticular and sigmoidal meter-sized layers of fine sandstones occasionally occur interbedded with this succession and are interpreted as distal deltaic mouth bar deposits (Lavina, 1991; Warren et al., 2008).
Discoid and ellipsoid carbonate concretions are particularly common in the fine-grained sandstone and mudstone beds of the Serrinha Member. From the intermediate portion of the Rio do Rasto succession, the change of gray pelitic facies from red and purple sediments, accompanied by the predominance of deltaic architectural elements, such as basin deposits, inter-distributary channels and crevasse splay lobes is remarkable.

The occurrence of facies associations deposited in different physiographic positions inside a deltaic or lacustrine environment can be expressed by the alternation of nearshore and offshore architectural elements. This particularity can be explained by the strong autocyclic character expected in deltaic depositional systems, which enables the constant migration of channels and consequently the interdistributary bay areas and deltaic mouths (Warren et al., 2008). On the second stratigraphic third of the Morro Pelado Member, the presence of aeolian architectural elements interbedded with subaqueous sedimentation is evidence of definitive continentalization and a transition to the Pirambóia desert system (Figs. 2, 3) (Lavina, 1991; Rohn, 1994; Warren et al., 2008). 

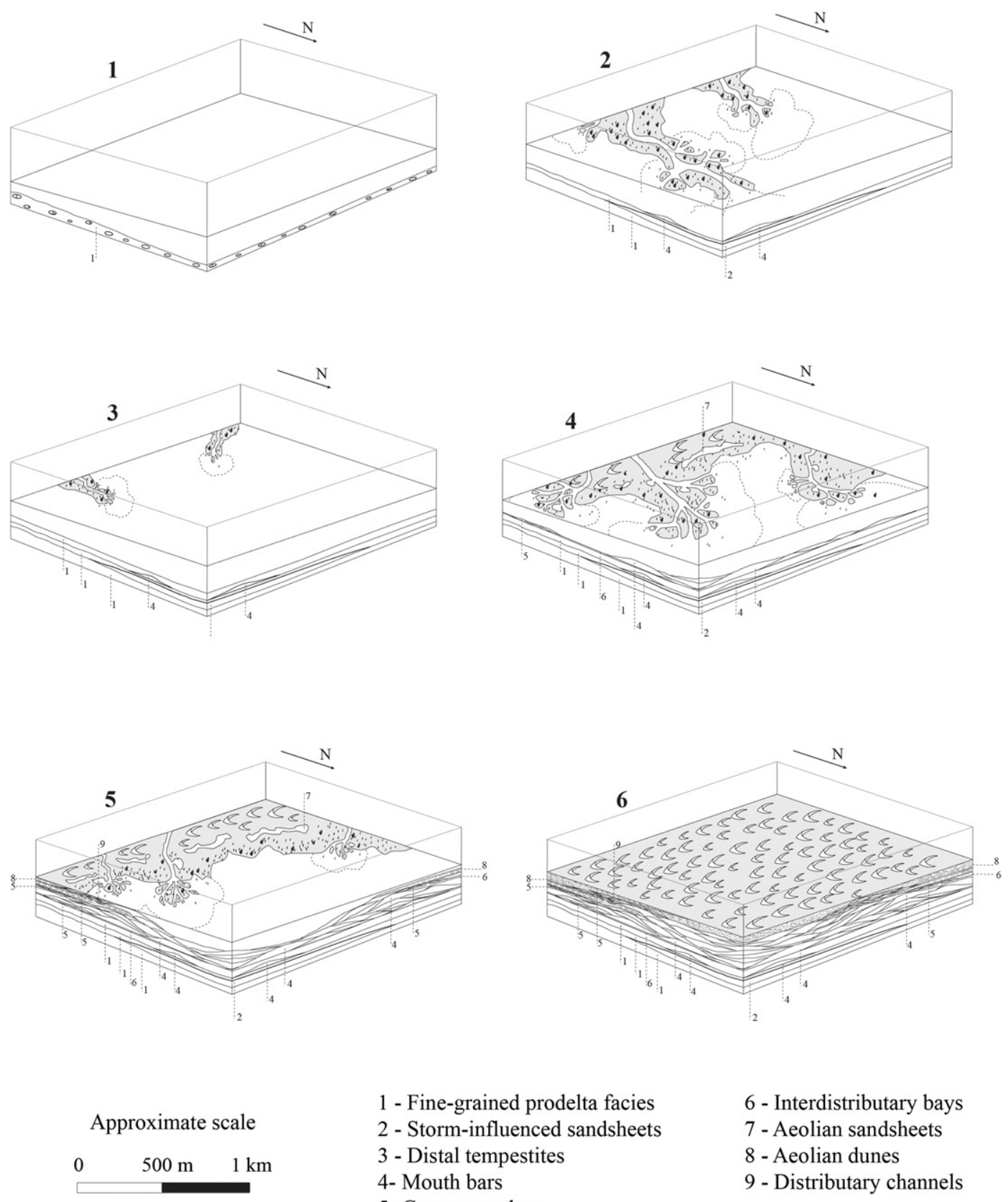

\author{
1 - Fine-grained prodelta facies \\ 2 - Storm-influenced sandsheets \\ 3 - Distal tempestites \\ 4- Mouth bars \\ 5- Crevasse-splays
}

6 - Interdistributary bays

7 - Aeolian sandsheets

8 - Aeolian dunes

9 - Distributary channels

Fig. 2. Block diagrams showing the sedimentary evolution of the Rio do Rasto Formation. Modified from Warren et al. (2008).

\section{Methodology}

The geometry, shape and size of the concretions were described and sampled at two localities in the southeastern region of the Santa Catarina State, Brazil (Sites 1 and 2). The compositional and textural features of the concretions, as well as the microscopic aspects of the Serrinha Member fine-grained sandstones, were investigated by petrographic analysis with an Olympus BX50 polarizing microscope. The concretion sub-samples used for carbon and oxygen isotopic analysis were extracted from pre-selected polished slabs using a tungsten carbide dental drill coupled to a Sherline 5400 benchtop sampler. The stable isotope analyses were performed at the Laboratório de Isótopos Estáveis, Centro de Pesquisas Geocronológicas (LIE-CPGeo) of the Instituto de Geociências, Universidade de São Paulo. Based on preliminary petrographic studies, 32 representative microsamples extracted at equal intervals from the edge-to-edge of each concretion and septarian cracks were selected for stable carbon and oxygen $\left({ }^{13} \mathrm{C}\right.$ and $\left.{ }^{18} \mathrm{O}\right)$ isotopic analysis. The concretionary bodies and crack fillings were analyzed separately. The stable oxygen and carbon isotope ratios are expressed in $\delta$ notation, the per mil (\%) deviation from the Vienna Pee Dee Belemnite (VPDB) standard: $\delta^{18} \mathrm{O}=\left[\left({ }^{18} \mathrm{O} /{ }^{16} \mathrm{O}\right)_{\text {sample }} /\right.$ $\left.\left.\left({ }^{18} \mathrm{O} /{ }^{16} \mathrm{O}\right)_{\mathrm{VPDB}}\right)-1\right] \times 1000$ for oxygen and $\delta^{13} \mathrm{C}=\left[\left({ }^{13} \mathrm{C} /{ }^{12} \mathrm{C}\right)_{\text {sample }} /\right.$ $\left.\left.\left({ }^{13} \mathrm{C} /{ }^{12} \mathrm{C}\right)_{\mathrm{VPDB}}\right)-1\right] \times 1000$ for carbon. For each measurement, approximately $150 \mu \mathrm{g}$ of powder was drilled from the sample and analyzed with an automated carbonate preparation system linked to a mass spectrometer (Finnigan Delta Plus Advantage). The analytical error of the carbon and oxygen isotope analysis was less than $0.1 \%$. We investigated the mineralogical composition and microtextures of the concretions using a scanning electron microscope (SEM) at the Centro de Pesquisas Geocronológicas of the University of São Paulo (VP-ESEM Model QUANTA $250 \mathrm{FEI}$, operated at EHT $20 \mathrm{kV}$ and 100 Pa pressure). Another aim of the SEM analysis was to produce compositional multi-element 


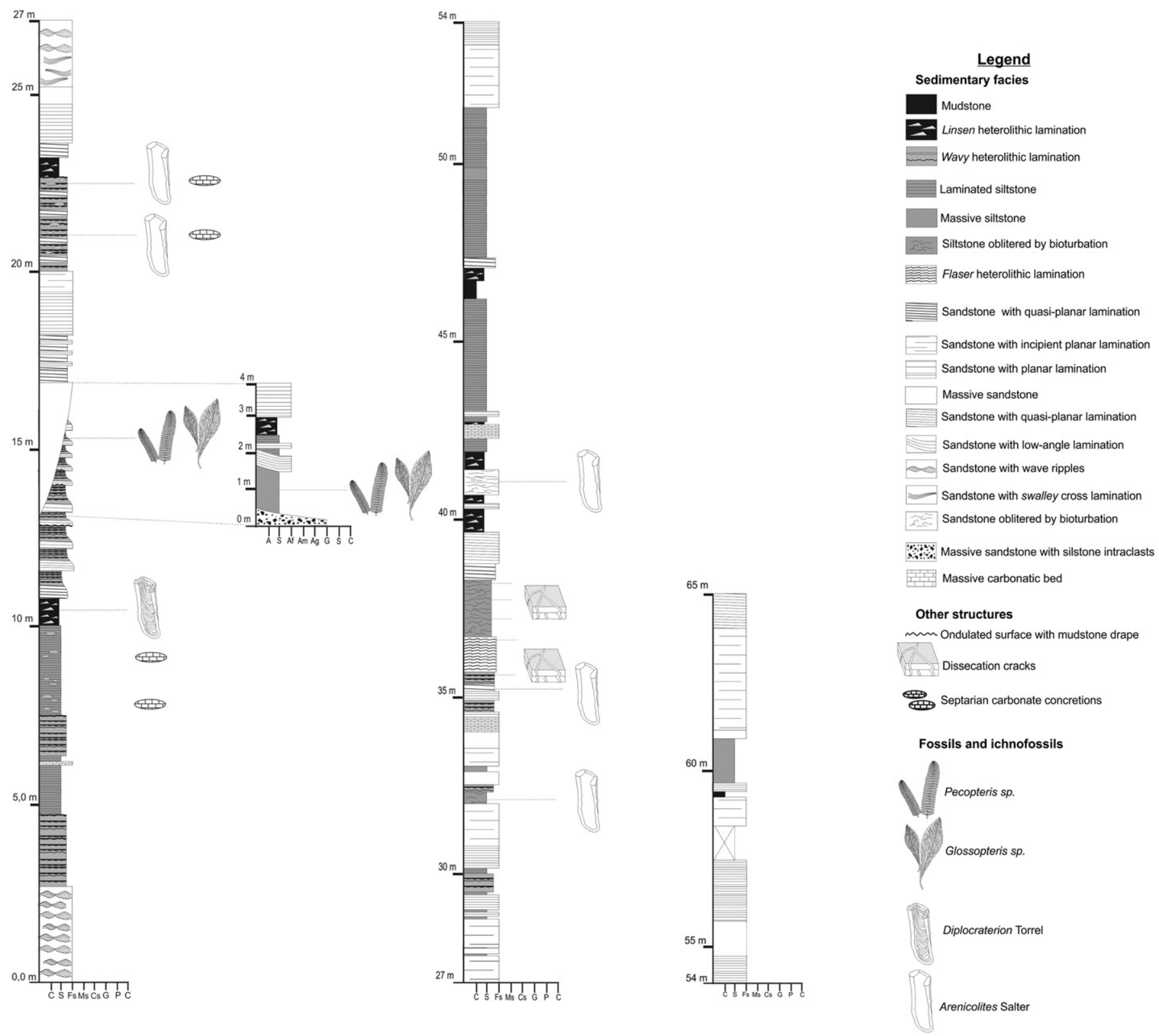

Fig. 3. Simplified stratigraphic column of the Serrinha Member. Adapted from Warren et al. (2008).

maps of the concretions using an SEM X-ray energy-dispersive spectrometer equipped with a dry solid-state silicon detector (Oxford Instruments Ltd.), controlled by INCA software. The samples were coated with a thin layer of carbon to prevent charging.

\section{Results}

\subsection{The host sediment}

The Serrinha Member was described by Schneider et al. (1974) as being composed primarily of greenish and purplish siltstones interbedded with shales, very fine-grained sandstones and rare carbonate lenses. The outcrops of the Serrinha Member in the vicinities of Lages city (Site 1) consist of tabular beds of interbedded gray mudstones and siltstones and also very fine-grained grayish sandstone layers (Fig. 4A, B). The outcrops that we studied in the Rio do Rasto Hills (Site 2) contain greenish gray mudstones and siltstones layers interbedded with massive or laminated very fine to fine-grained sandstones beds (Fig. 5A, B). The host sandstones have a rather uniform composition of monocrystalline quartz (75\%), feldspars (15\%), heavy minerals $(<1 \%)$ and undifferentiated clay minerals $(10 \%)$. The sandstone framework is composed of very fine, rounded to sub-rounded and well-sorted grains.

\subsection{Macroscopic characteristics of the concretions}

The septarian carbonate concretions were found exclusively in the lower portion of the Rio do Rasto Formation within the sediments of the Serrinha Member. They are hosted in mudstones and very finegrained sandstones either as isolated concretions (Figs. 4A, B, C, 5C, D, E) or as continuous, flattened, strata-bound layers (Fig. 4B). Deformational synsedimentary structures, such as clastic dykes, liquefaction/ dewatering features or load casts, were not observed between the concretions and the surrounding mudstones and sandstones. The 

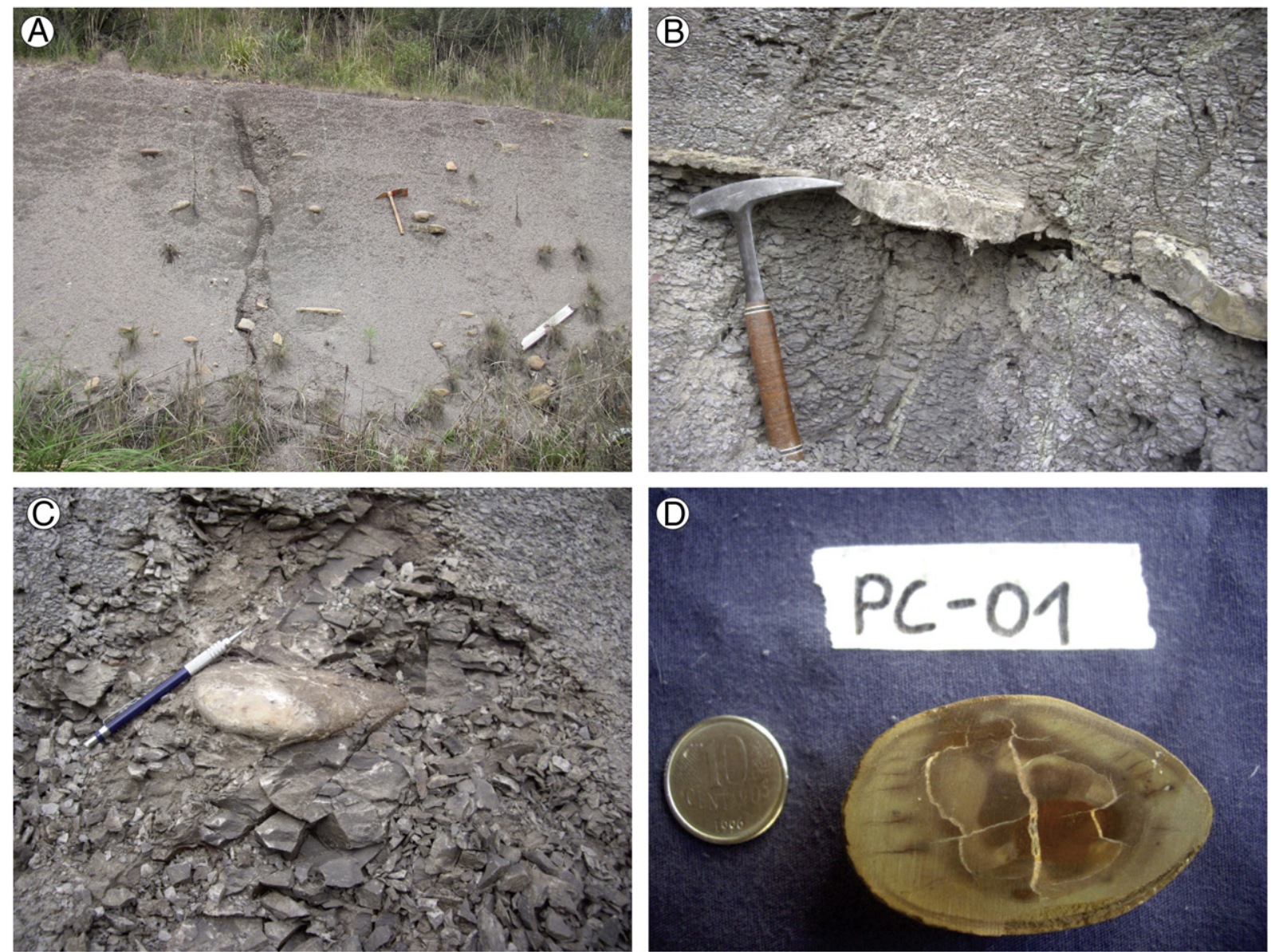

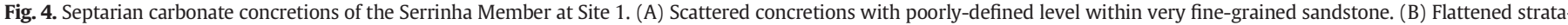
bound concretion. (C) Disk-shaped concretion. (D) Photograph of vertical section of a concretion containing septarian fractures.

horizontal spacing between individual concretions ranges from fewer than $5 \mathrm{~cm}$ to $1 \mathrm{~m}$ (Figs. 4A, 5E). The larger concretions were much flatter than the smaller ones, revealing a tendency toward spheroidal form (Fig. 5E). The larger axis of the flattened concretions is typically parallel to the bedding plane. The concretions show a weathered and exfoliated outer skin, and the central portion in which the septarian cracks developed, crosscuts radially toward the edge of the concretions. According to their shapes, we divided the concretions into four types: spherical to sub-spherical, flattened-ellipsoidal, horizontally flattened and tubular.

\subsection{Petrography of the concretions}

The carbonate concretions entrap and preserve minerals with a sedimentary and authigenic/diagenetic origin. All of the examined concretions are cemented with a mixture of micritic calcite $(<5 \mu \mathrm{m})$ and mosaics of microspar $(>5 \mu \mathrm{m})$, with very fine-grained monocrystalline detrital quartz and undifferentiated clay minerals. Clay minerals and carbonate cements are arranged in the concretion matrixes with faceto-face and edge-to-face grain contacts, which form a cardhouse texture (Fig. 6E). The dominant authigenic phases are calcite, barite and apatite (0.03-0.08 mm). A decreasing proportion of carbonate cement relative to detrital grains occurs toward the concretion edges (Fig. 7A). Prominent internal septarian fractures $(0.1-2 \mathrm{~mm}$ wide) filled with calcite are the widest in the concretionary bodies (Figs. 4D, 5E, 6A, B, C, F, 7A, $B)$. Fracture filling is much more common in the central portion of the concretions, and the fractures do not intercept or cut the concretion surfaces (Figs. 4D, 5F). The septarian fractures are more compacted in the outer portions (edges) of the concretions (Figs. 4B, 6A, B). The calcite content in the concretions is notably higher than in the host finegrained sandstone. Calcite is the predominant mineral filling the septarian cracks, followed by the less abundant barite. We found that the barite crystals typically developed perpendicular to the walls of the septarian fractures, with their longest axes ranging from 0.1 to $0.3 \mathrm{~mm}$ (Figs. 6F, 8).

Carbonate concretions from Site 1 (varying according to the recrystallization degree) are composed of a framework of randomly distributed domains of micrite $(<5 \mu \mathrm{m})$ and microspar $(>5 \mu \mathrm{m})$ cement, which also contains very fine-grained angular monocrystalline detrital quartz with minor amounts of diagenetic apatite $(0.03-0.06 \mathrm{~mm})$, barite and undifferentiated clay minerals (Figs. 6, 8). The concretions also show a complex internal structure characterized by fractures (widths between 0.5 and $1 \mathrm{~mm}$ ) mainly filled with fibrous and granular calcite grains (Fig. 6A, B, C) that do not extend to the concretion edge. Prismatic barite crystals also occur as a secondary mineral in the septarian fractures (Fig. 6F).

The concretions from Site 2 consist mainly of a mixture of subangular to angular, very fine-grained monocrystalline quartz grains embedded in a micritic-microspar cement. A horizontal/vertical network of small-scale septarian cracks $(0.1-1 \mathrm{~mm})$ filled with calcite cement crosscut the concretion. The calcite cement in the fracture fillings is found in two forms, suggesting two episodes of calcite filling: (i) an earlier phase that consists of druses with very fine-grained calcite crystals that grow toward the interior of the cracks and (ii) a later phase that consists of blocky, very fine-grained euhedral calcite crystals, forming a mosaic of cement between the grains (Fig. 7A, B). The content of detrital terrigenous grains increases from the center to the edge of the concretion (Fig. 7A). 

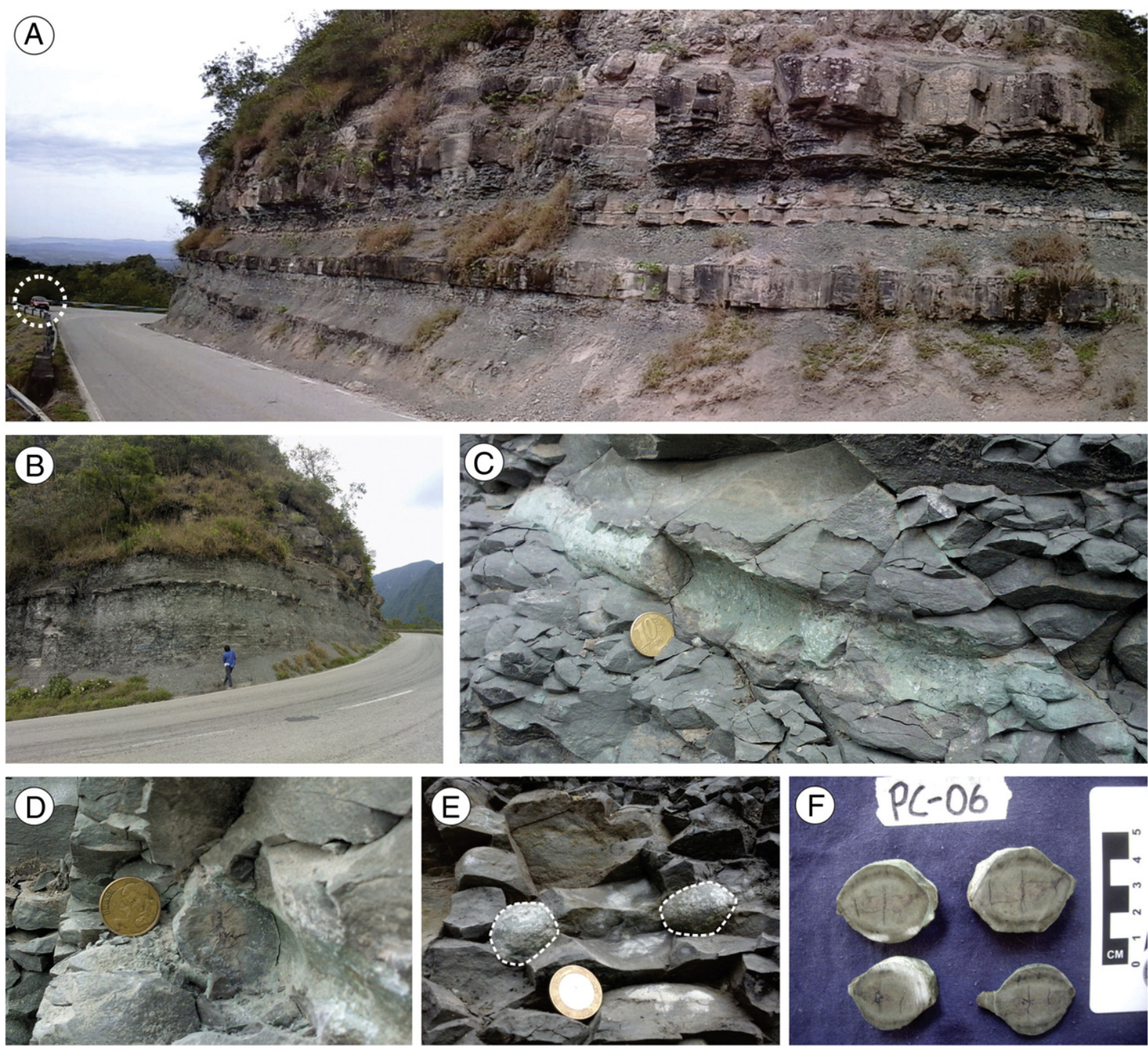

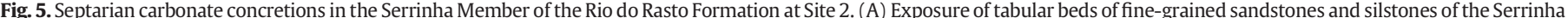

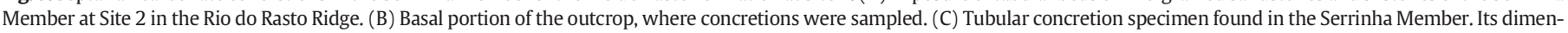

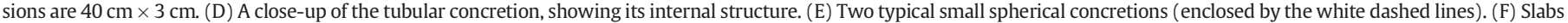
for petrographic and isotopic analysis.

\subsection{Electron microprobe analysis of authigenic phases within concretions}

The geochemical compositions and $\mathrm{Mg} / \mathrm{Ca}$ ratios of authigenic carbonates are listed in Table 3. The $\mathrm{Mg} / \mathrm{Ca}$ molar ratio can be used to discriminate the presence of high-Mg carbonates, low-Mg calcite and terrigenous fractions (Bayon et al., 2007). Both matrix cements and septarian fractures in the carbonate concretions of the Serrinha Member display similar $\mathrm{Mg} / \mathrm{Ca}$ ratios, between $0.49-0.65$ and $0.57-0.64$, respectively. Scanning electron microscope observations on the Serrinha Member concretions revealed that the fracture fillings are composed of carbonates with low contents of magnesium and manganese (Fig. 8). The matrix cement, composed of a complex framework of micrite/microspar and detrital minerals, presents moderate $\mathrm{Al}, \mathrm{K}$ and $\mathrm{S}$ contents (Fig. 8).

\subsection{Carbon and oxygen isotopic signatures}

Stable oxygen and carbon isotope values obtained for the powders extracted from the concretion cement and septarian cracks are listed in Table 1. Both the oxygen and carbon isotope data show mainly negative values, revealing little difference between the values obtained from the cores and rims of the concretions. The range of $\delta^{18} \mathrm{O}$ values is rather wide ( -14.4 to $-2.6 \%$ PDB); the range of $\delta^{13} \mathrm{C}$ values is more limited $(-5.0-0.2 \%$ o PDB).

In Site 1, the carbon isotope values for the calcite cement range between -5.0 and $-3.7 \%$, with a mean value of $-4.4 \%$ ( $P D B)$. For the septarian cracks, the $\delta^{13} \mathrm{C}$ values vary between -4.4 and $-3.3 \%$, with a mean value of $-3.9 \%$ ( $P D B$ ). The oxygen isotope values for the calcite cement range from -12.1 to $-7.1 \%$ o $(\mathrm{PDB})$. For the fracture fillings, the $\delta^{18} \mathrm{O}$ values vary between -14.4 and $-13.8 \%$ (PDB). Despite some scattering, three main clusters are evident when we plot $\delta^{13} \mathrm{C}$ versus $\delta^{18} \mathrm{O}$ (Fig. 8). Cluster 1 corresponds to matrix cement of sample PC-06 (Site 1$)$, with isotopic signatures $\left(\delta^{13} \mathrm{C}:-4.6\right.$ to $-4.4 \%$, $\delta^{18} \mathrm{O}$ : -10.0 to $-7.1 \%$ ). Cluster 2 involves matrix cement mainly from samples PC-02 and PC-03. Cluster 3 represents the fracture filling isotopic signatures. In Site $2, \delta^{13} \mathrm{C}$ values for the matrix cement range from -4.6 to $0.2 \%$ ( $\mathrm{PDB}$ ), and the oxygen isotopic values vary between -9.1 and $-2.6 \%$ ( $\mathrm{PDB}$ ). When we only consider the oxygen and carbon isotopes, the analyzed concretions do not show significant systematic differences in isotopic composition, suggesting that the fluid sources were very similar. 

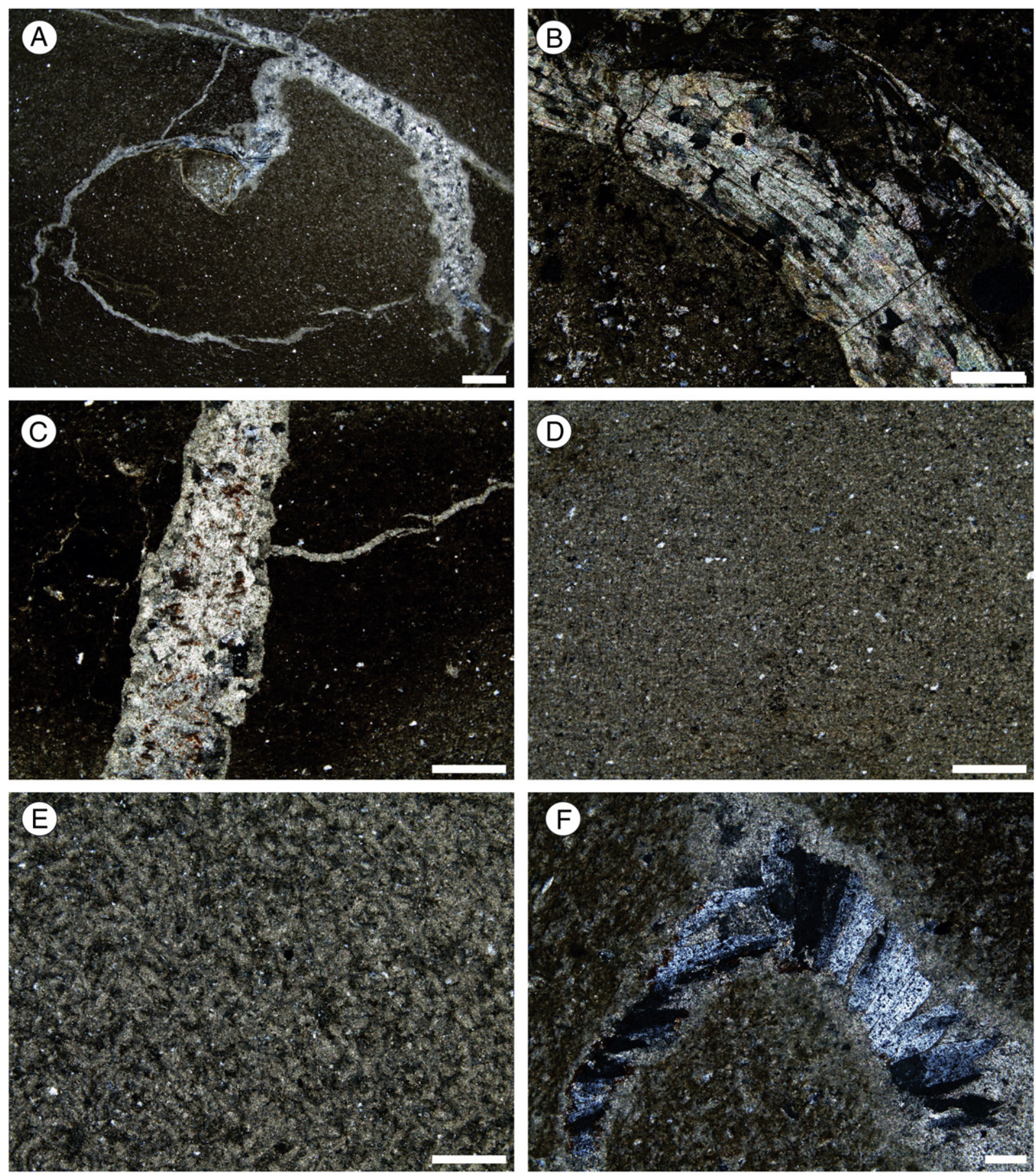

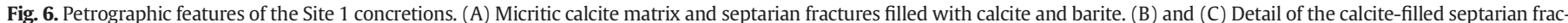

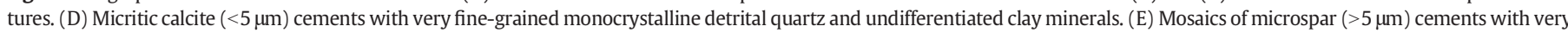

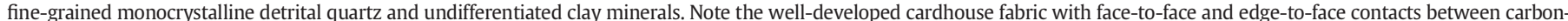
ates. (F) Bladed barite crystals filling septarian fractures. Scale bars: For A $-1 \mathrm{~mm}$; for B, C, D and E $-0.5 \mathrm{~mm}$ and for F $-0.1 \mathrm{~mm}$.

\section{Discussion}

Carbonate concretions hosted in sedimentary rocks are typically thought to be formed from cementation promoted by the circulation of interstitial pore waters within sediments during diagenesis (Irwin et al., 1977). Stable $\delta^{13} \mathrm{C}$ and $\delta^{18} \mathrm{O}$ isotopic signatures of concretions have been used to track shifts in parameters, such as water temperature and composition, salinity, primary productivity and nutrient availability (Rodrigues and Fauth, 2013). Therefore, these isotopic signatures can provide reliable information for paleoenvironmental reconstructions, detection of anoxic events and glacial, interglacial and postglacial periods (Hoefs, 2004).
The septarian carbonate concretions from the Serrinha Member exhibit geochemical and textural features suggestive of an early diagenetic formation within the host rocks. The concretions appear to have been formed during shallow burial by progressive concentric cementation (Irwin et al., 1977; Astin, 1986; Mozley, 1996) as demonstrated by the following geochemical and textural evidence: (i) a decreasing proportion of carbonate cement relative to detrital grains from the concretion center toward the edges, (ii) a high degree of compaction experienced by the septarian fractures close to the concretion edges and (iii) coreto-rim isotopic shifts. The preservation of a cardhouse microtexture within the concretions reflects a shallow depth of carbonate precipitation, 

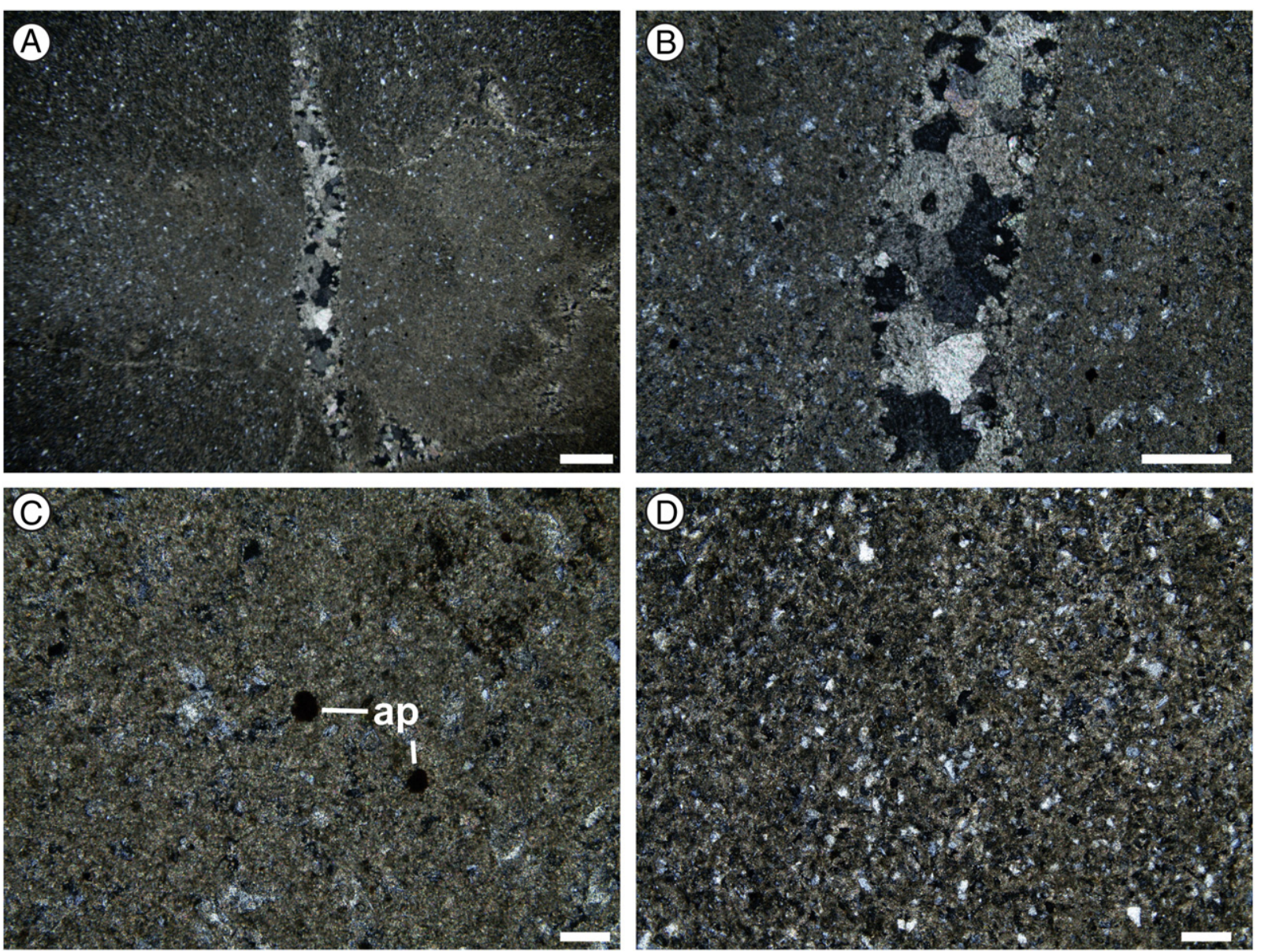

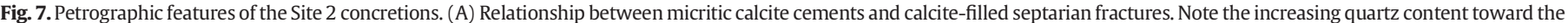

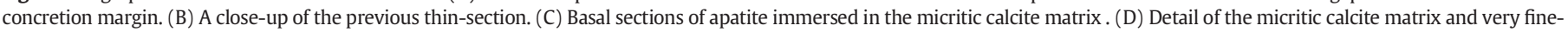
grained monocrystalline detrital quartz and undifferentiated clay minerals. Scale bars: For A - $1 \mathrm{~mm}$; for B and D - $0.5 \mathrm{~mm}$ and for C - $0.1 \mathrm{~mm}$. Marker for: ap - apatite.

with nucleation and growth probably starting no more than a few tens of meters below the sediment-water interface. Carbonate cement protected this microtexture from deformation and chemical reactions during the subsequent burial. Astin (1986), based on textural evidence, showed that septarian fracturing will be favored by overpressuring and low horizontal stress, similar to what occurs during times of rapid burial. However, the development of diagenetic barite is closely linked to low rates or breaks in sedimentation, as demonstrated by Bréhéret and Brumsack (2000). Thus, it seems that the calcite precipitation within the septarian cracks of the Serrinha Member concretions is indicative of an initial phase of rapid burial followed by a decrease in the sedimentation rate, represented by neo-formed barite crystals. The lack of barite in the early stages of concretion growth may suggest a low sulfate concentration during deposition. Additionally, the precipitation of barite indicates removal of sulfate ions from the interstitial pore waters. This is important because sulfate ions inhibit carbonate precipitation (Compton, 1988), indicating that during the late barite crystallization within the septarian fractures, carbonate precipitation was finished. Early authigenic carbonate cementation in these concretions established a closed microsystem that acted as a shield for the minerals and textures during the subsequent burial and diagenesis. The chemical variations from the center to the rim are indicative of progressive (or temporal) alterations in the pore water compositions.

$\mathrm{Mg} / \mathrm{Ca}$ molar ratios determined in the concretions showed characteristic values that were used to distinguish between authigenic aragonite, high-Mg calcite, dolomite and calcite (Bayon et al., 2007). Lowenstein et al. (2001) presented the major-ion composition of
Permian seawater based on fluid inclusions in marine halites from Late Permian strata of North America. They showed that Permian and modern seawater are both classified as aragonite seas, with $\mathrm{Mg} / \mathrm{Ca}$ ratios $>2$. Unlike carbonates precipitated from aragonite seas, the carbonate phases analyzed here display $\mathrm{Mg} / \mathrm{Ca}$ molar ratios between 0.49 and 0.65 , indicative of supersaturation with respect to calcite rather than dolomite.

Negative $\delta^{18} \mathrm{O}$ values for early diagenetic carbonates crystallized in marine siliciclastic successions can be explained by different processes: (1) an influx of meteoric water, (2) oxidation of organic matter in the sulfate-reduction zone, (3) chemical interaction between sea water and sediments with volcanogenic or juvenile materials, (4) the ascension of hot fluids and (5) increasing temperature and recrystallization of early carbonate cement during deep burial (Morad et al., 1996). Meteoric water can exhibit a wide variation in $\delta^{18} \mathrm{O}$ values between -40 and $10 \%$ ( $\mathrm{PDB}$ ). However, the carbonates that precipitate in warm waters tend to incorporate more ${ }^{16} \mathrm{O}$ than ${ }^{18} \mathrm{O}$, resulting in lower $\delta^{18} \mathrm{O}$ values (Armstrong and Brasier, 2005). Meteoric water from arid regions exhibits a large range of $\delta^{18} \mathrm{O}$ values, but normally, such water is depleted in ${ }^{18} \mathrm{O}$ relative to seawater (negative $\delta^{18} \mathrm{O}$ values) (Magaritz, 1980). Lacustrine carbonates possess significant variations in $\delta^{18} \mathrm{O}$ isotopic composition depending mainly on (1) the isotopic composition of the rainwater in the hydrographic basin area, (2) the availability and seasonality of the rainwater, (3) temperature, (4) evaporation rate, (5) relative humidity, and (6) biological productivity. Marine water, in contrast, commonly exhibits positive $\delta^{18} \mathrm{O}$ values ranging between 0 and $2 \%$ (Hoefs, 2004), and marine carbonates precipitated during 

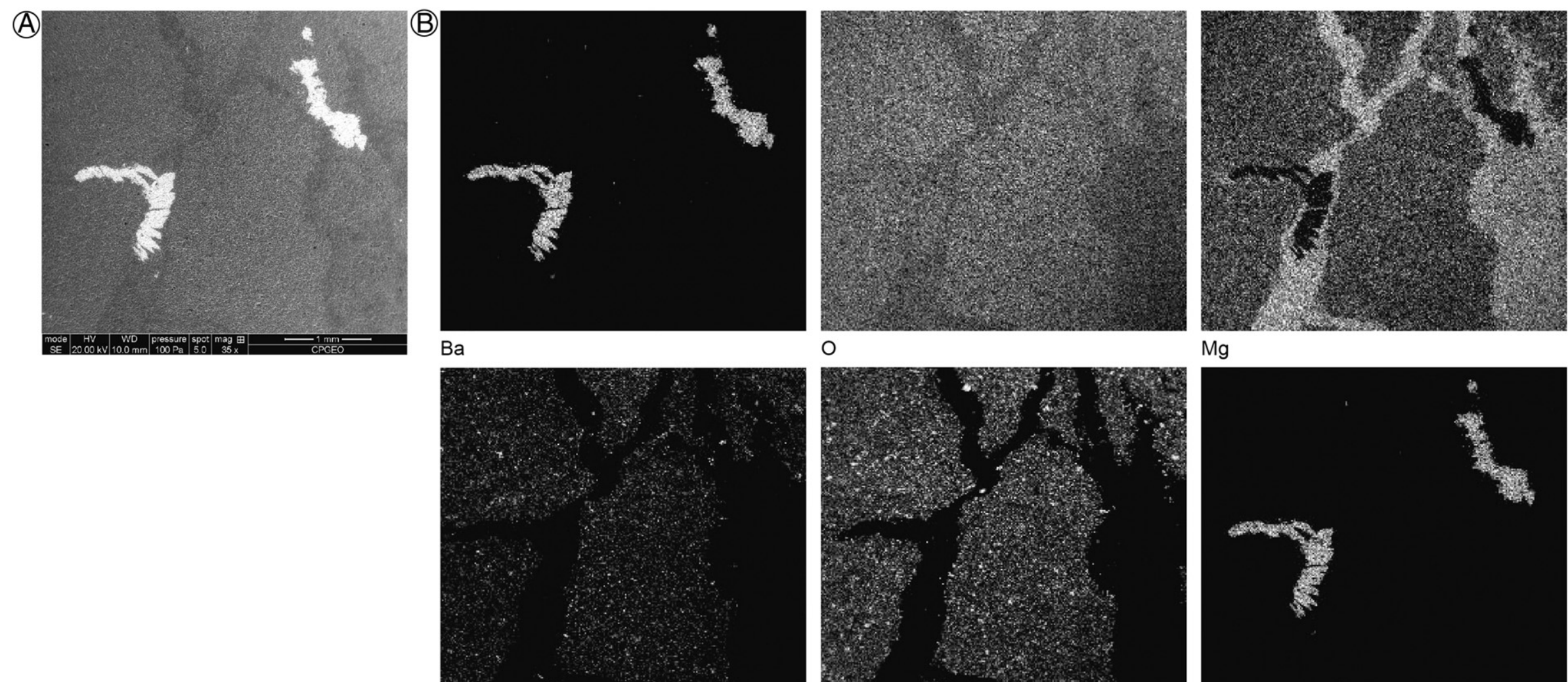

$\mathrm{Mg}$

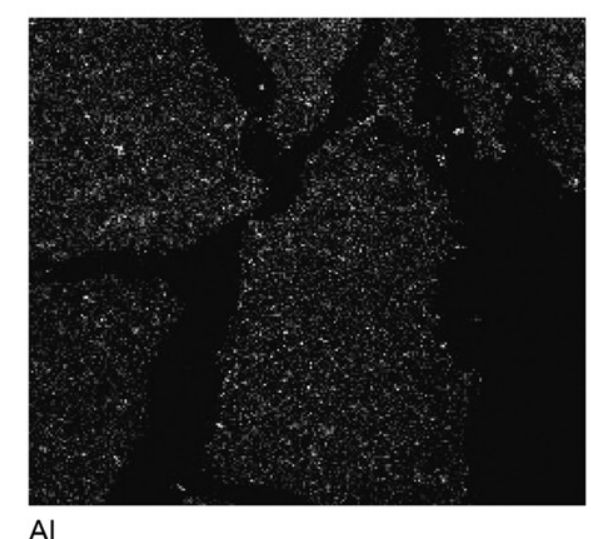

A

Si
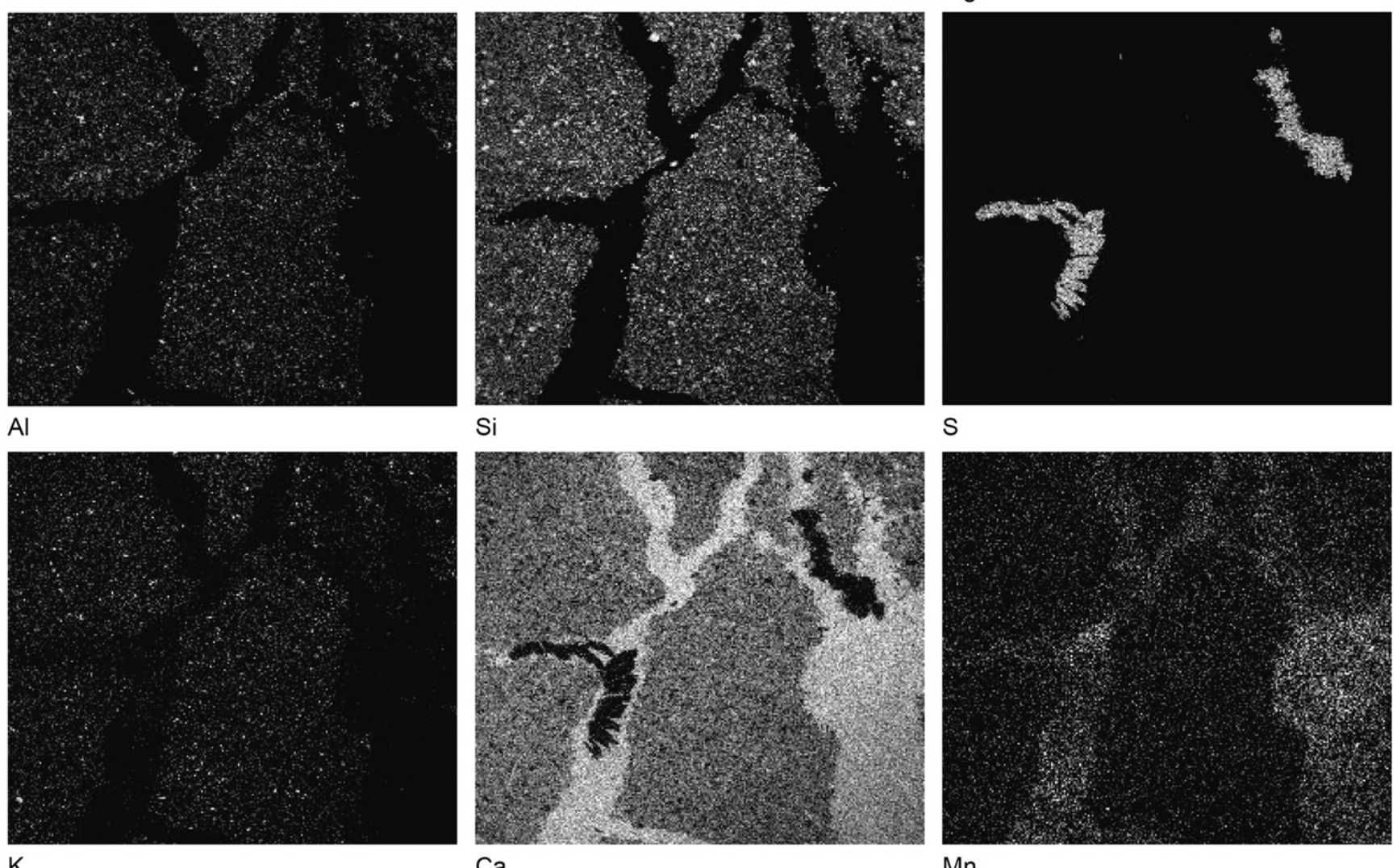

$S$

$\mathrm{K}$

Ca

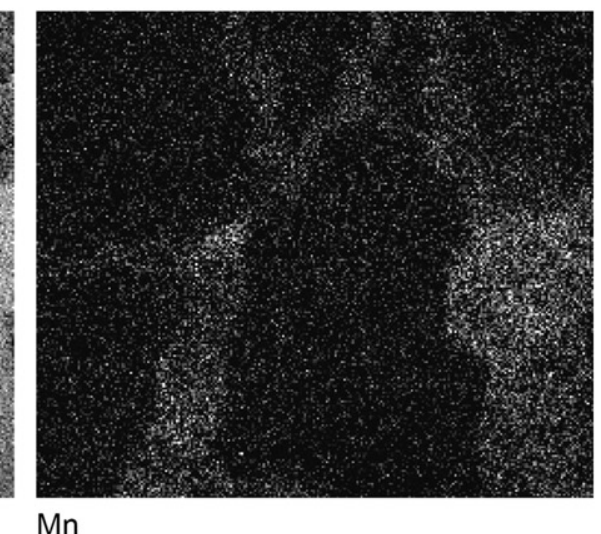

Fig. 8. Compositional maps for the concretion PC-01 obtained by scanning electron microscope observations. 


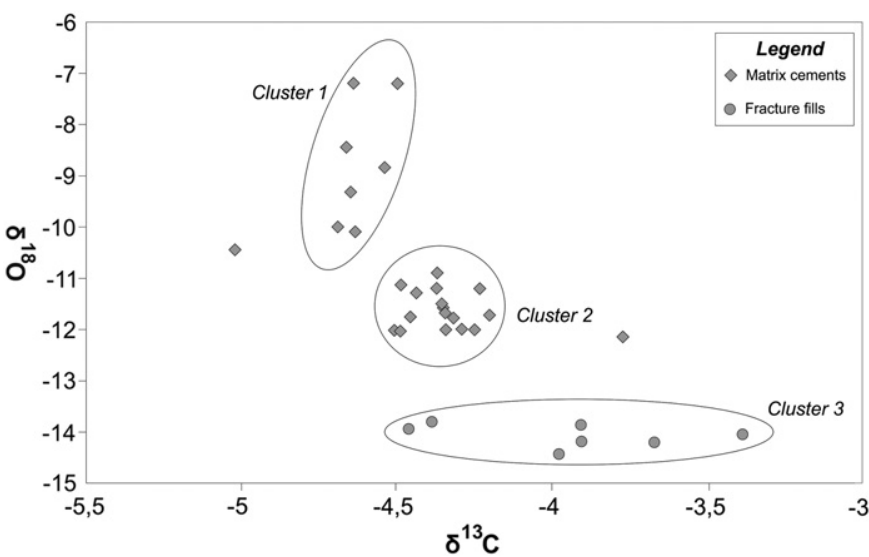

Fig. 9. Cross-plot of $\delta^{13} \mathrm{C}$ versus $\delta^{18} \mathrm{O}$ for matrix and septarian fractures in the concretions.

greenhouse or interglacial periods have lighter ${ }^{18} \mathrm{O}$ values than those precipitated during glacial epochs (Armstrong and Brasier, 2005).

Both carbonate cement and the subsequent calcite filling fractures of the concretions in the Serrinha Member yield negative $\delta^{18} \mathrm{O}$ values varying between -14.4 and $-7.1 \%$ (PDB). Despite some evidence for ash fall deposits in the Paraná Basin sequence (Matos et al., 2001; Guerra-Sommer et al., 2005, 2008a,b; Rocha-Campos et al., 2006, 2007; Santos et al., 2006; Mori et al., 2012; Cagliari et al., 2014), there is no direct evidence for intrabasinal volcanic activity during the Permian Period, permitting us to discard the large-scale chemical interaction between sediments and volcanic materials to explain the negative values of $\delta^{18} \mathrm{O}$ found in the concretions. Likewise, there is no conclusive evidence of hydrothermal or metamorphic processes of percolation of hydrocarbon-rich fluids from the overlying hydrocarbon source units (i.e., the Rio Bonito and Irati formations; Milani and Zalán, 1999; Araújo et al., 2000). As a result, an interaction between heated fluids and the Serrinha Member sediments cannot be considered the main mechanism responsible for the low $\delta^{18} \mathrm{O}$ values. Finally, we consider that the petrographic evidence presented associated with the low $\delta^{18} \mathrm{O}$ values of the carbonate concretions corroborates the hypothesis of an authigenic and early diagenetic origin with nucleation and growth in the sediment-water interface, possibly in low-saline or freshwater conditions.

The computational paleotopographic models of Roscher et al. (2011) for the Permo-Triassic boundary show that the Gondwanides orogenic belt reached maximum elevations of approximately $3000 \mathrm{~m}$ above sea level, configuring the largest and highest mountain chain in southern Gondwana (Fig. 10). This orographic barrier certainly affected not only the marine connections and incursions into the continent but also the climatic conditions in the central portions of Gondwana. According to paleoclimatic reconstructions of Limarino et al. (2013) and Benton and Newell (2013), the study area experienced a semiarid to arid climatic period between the Middle Guadalupian-Lopingian. These authors attributed this climatic condition to climate continentalization caused by the Gondwanides mountain barrier. Modern-day analogs for this scenario are the Andean Cordillera in South America and the Himalayan Mountains in Asia, of which the high altitude of the cordillera strongly affects the atmospheric circulation and, consequently, the inland climatic patterns. Paleoclimatic data for the Permian-Triassic boundary also indicate warm temperatures in polar regions (Retallack, 1995). The regional evidence for a warm climate suggests that the Serrinha Member was deposited in a basin located in the middle to high latitudes under semi-arid conditions (Kiehl and Shields, 2005) (Fig. 10).

Visser (1995), based on lithological and paleontological data, concluded that the continental surface area covered by water in southwestern Gondwana reached a maximum of $34 \%$ during the

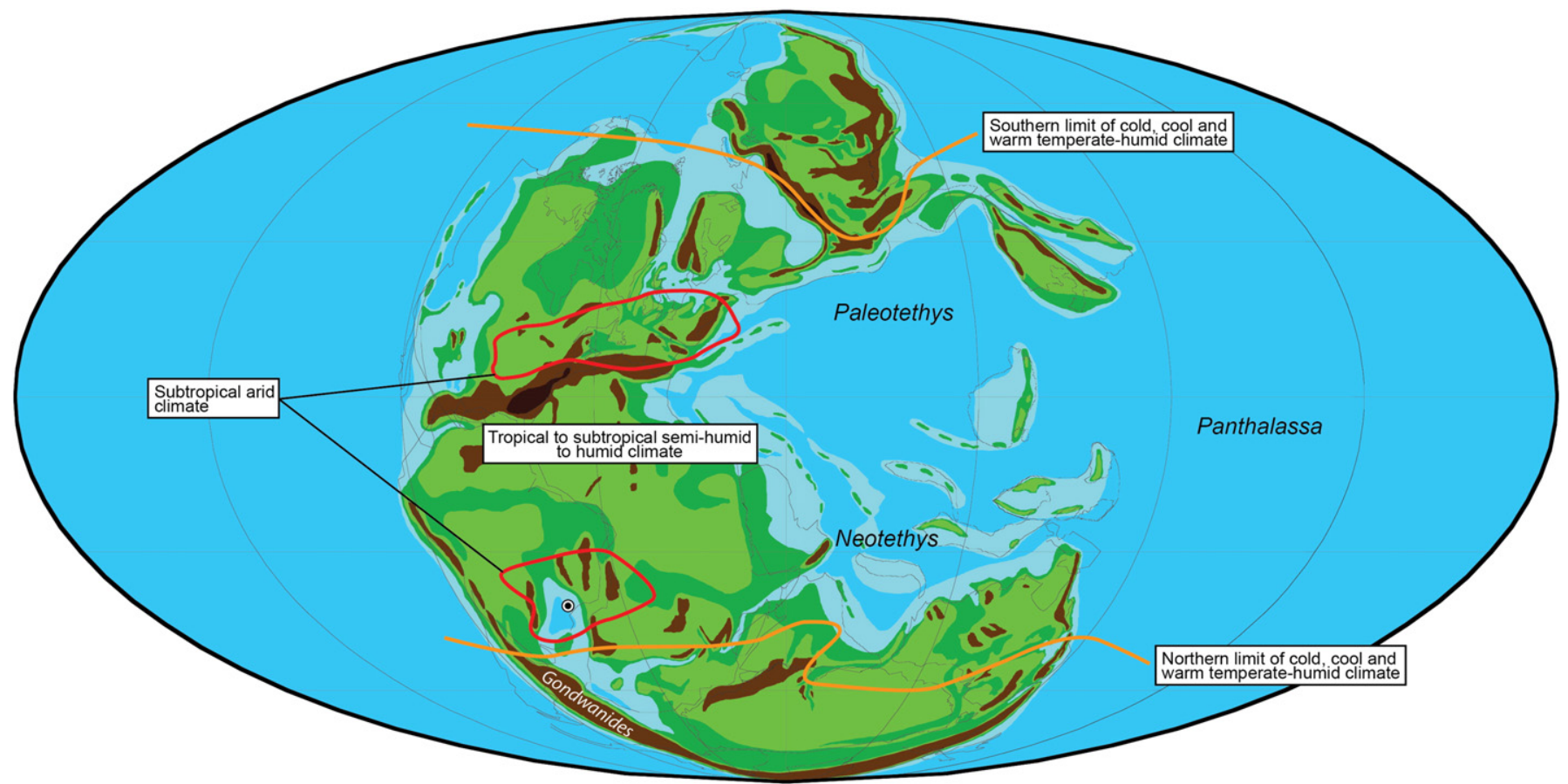

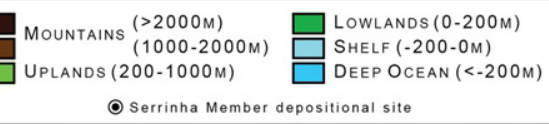

Fig. 10. Late Permian paleogeography, showing major geographical and climatic regions. Modified from Ziegler et al. (1997). 


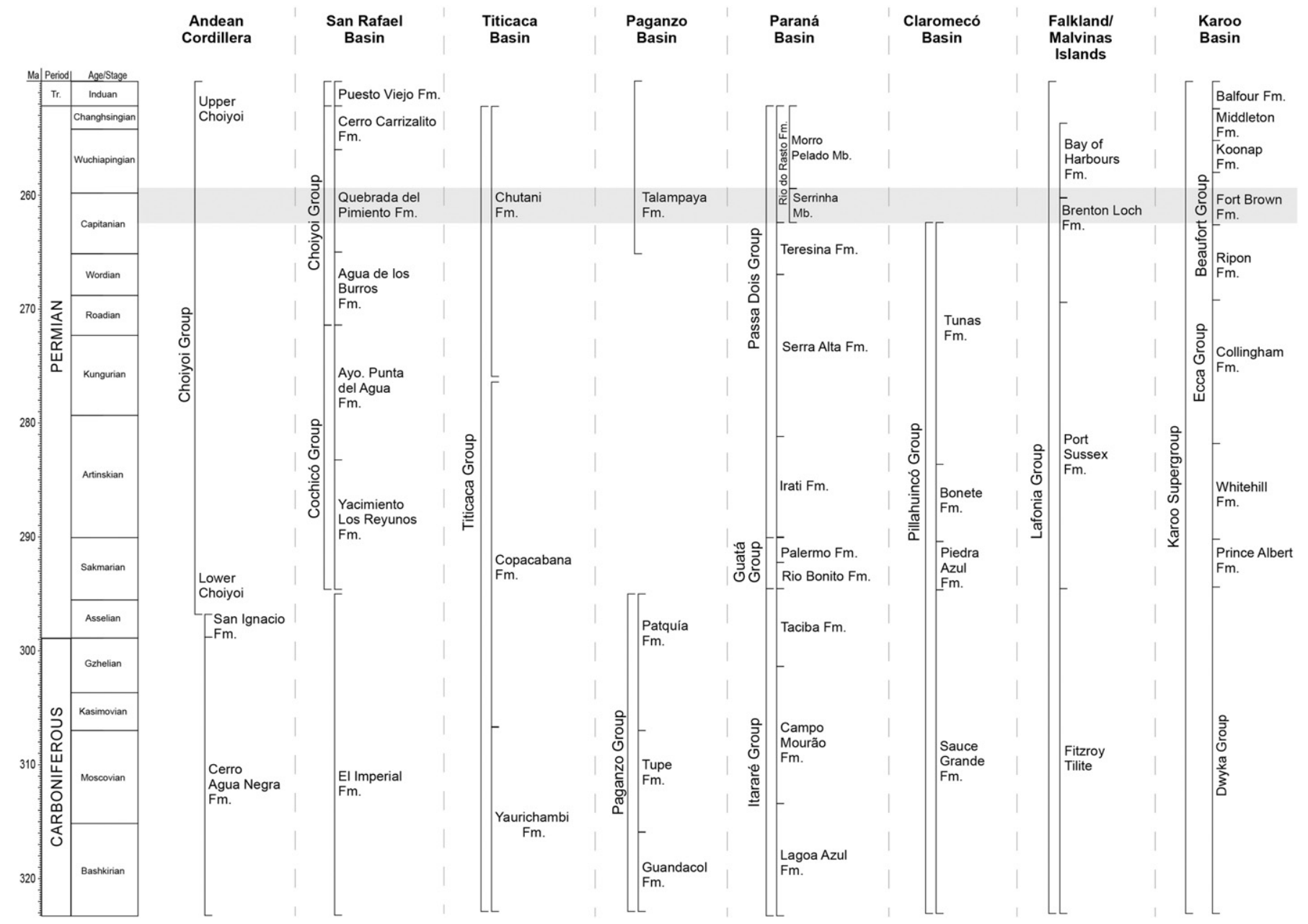

Fig. 11. Stratigraphy of the major late Paleozoic basins in southern South America. Modified from Limarino et al. (2013).

Early-Late Permian and decreased to approximately 6\% at the Permo-Triassic passage. Visser also argued that this huge interior water body reached its maximum extent at the Karoo and Paraná basins during the middle Permian. Yemane (1993) suggested the existence of coeval giant lakes, possibly interconnected throughout southwestern Gondwana during the Late Permian. The absence of typical marine macro- and microfossils (e.g., echinoderms, bryozoans, brachiopods and foraminifera), glauconite deposits and sedimentary structures indicative of tidal influence (such as tidal bundles) suggests a lack of, or restricted, marine influence on the deposition of the Permian-Triassic successions in southwestern Gondwana basins. Supporting this hypothesis, an unusual ichnofossil assemblage associated with freshwater bivalves recently described in the Brenton Loch Formation of the Falkland/Malvinas Islands strongly suggests non-marine conditions for the Late Permian in the Paraná, Falkland and Karoo basins (Fig. 11, Table 2) (Simões et al., 2012). The data presented here and discussed together with other information available in the literature attest to the existence of an epicontinental freshwater body fed by fluvio-deltaic systems in the Paraná Basin during the Late Permian. This premise also favors the idea that the concretions of the Serrinha Member were formed under the influence of meteoric water/freshwater. Furthermore, this scenario suggests that the restricted basin was supplied primarily by meteoric water influxes derived from continental runoff, rivers and rain. In this context, the negative $\delta^{18} \mathrm{O}$ values of the carbonate cement and fracture fills of the Serrinha Member concretions can also be related to a decrease in water salinity caused by the addition of freshwater in the eperiric water body.

Carbon isotopic signatures provide important information about paleoproductivity and the availability of nutrients in oceans and lakes (Irwin et al., 1977; Curtis and Coleman, 1986). According to Hoefs (2004) and Armstrong and Brasier (2005), marine carbonates are isotopically heavier, with average $\delta^{13} \mathrm{C}$ values of approximately $0 \%$. However, non-marine carbonates are isotopically lighter, with mean values between 0 and $-18 \%$. The major processes responsible for $\delta^{13} \mathrm{C}$ fractionation in lacustrine and marine environments are (1) primary productivity in the surface water, which removes ${ }^{12} \mathrm{C}$ from the environment and results in more positive $\delta^{13} \mathrm{C}$ values; (2) temperature fluctuations; ( 3 ) oxidation due to biological degradation of organic matter, which results in the return of ${ }^{12} \mathrm{C}$ to the water column and lighter $\delta^{13} \mathrm{C}$ values; (4) water recirculation and mixing, which carries ${ }^{13} \mathrm{C}$ to the surface; (5) micro-habitat effects; (6) coal-swamp deposits formed as a result of the increase in primary productivity; (7) the influence of metabolic processes of many different species associated with carbonate precipitation; and (8) diagenetic processes in which interstitial fluids tend to capture ${ }^{12} \mathrm{C}$, resulting in slightly negative $\delta^{13} \mathrm{C}$ values (Armstrong and Brasier, 2005).

The negative $\delta^{13} \mathrm{C}$ values of the Serrinha Member concretions between -3.7 and $0.2 \%$ (PDB) suggest low rates of primary productivity in the freshwater body. The absence of interbedded organic carbon-rich sediments in the Serrinha stratigraphic level reinforces the low rate of bioproductivity and the preservation of organic 
Table 1

Stable isotope $\left(\delta^{13} \mathrm{C}\right.$ and $\left.\delta^{18} \mathrm{O}\right)$ data for the calcite micritic matrix and septarian fractures in the Serrinha Member concretions.

\begin{tabular}{|c|c|c|c|}
\hline & Sample & $\delta^{13} \mathrm{C}(\mathrm{PDB})$ & $\delta^{18} \mathrm{O}(\mathrm{PDB})$ \\
\hline \multicolumn{4}{|l|}{ Site 1} \\
\hline \multirow[t]{9}{*}{ Septarian fracture } & PC1-16 & -4.23 & -11.20 \\
\hline & PC1-15 & -5.02 & -10.45 \\
\hline & PC1-14 & -4.39 & -13.80 \\
\hline & PC1-13 & -4.46 & -13.94 \\
\hline & PC1-12 & -3.39 & -14.05 \\
\hline & PC1-11 & -3.98 & -14.43 \\
\hline & PC1-10 & -3.90 & -14.19 \\
\hline & PC1-09 & -3.67 & -14.20 \\
\hline & PC1-08 & -3.91 & -13.86 \\
\hline \multirow[t]{16}{*}{ Matrix } & PC2-32 & -4.49 & -11.13 \\
\hline & PC2-31 & -4.37 & -10.90 \\
\hline & PC2-30 & -4.37 & -11.20 \\
\hline & PC2-29 & -4.44 & -11.29 \\
\hline & PC2-28 & -4.35 & -11.58 \\
\hline & PC2-27 & -4.34 & -11.68 \\
\hline & PC2-26 & -3.77 & -12.15 \\
\hline & PC2-25 & -4.32 & -11.78 \\
\hline & PC2-24 & -4.35 & -11.50 \\
\hline & PC3-39 & -4.51 & -12.02 \\
\hline & PC3-38 & -4.29 & -12.00 \\
\hline & PC3-37 & -4.34 & -12.01 \\
\hline & PC3-36 & -4.25 & -12.01 \\
\hline & PC3-35 & -4.20 & -11.72 \\
\hline & PC3-34 & -4.46 & -11.76 \\
\hline & PC3-33 & -4.49 & -12.04 \\
\hline \multirow[t]{7}{*}{ Site 2} & PC6-07 & -4.63 & -10.09 \\
\hline & PC6-06 & -4.69 & -10.00 \\
\hline & PC6-05 & -4.65 & -9.32 \\
\hline & PC6-04 & -4.54 & -8.84 \\
\hline & PC6-03 & -4.66 & -8.45 \\
\hline & PC6-02 & -4.50 & -7.20 \\
\hline & PC6-01 & -4.64 & -7.20 \\
\hline
\end{tabular}

matter in this interval. Moreover, the negative $\delta^{13} \mathrm{C}$ values also suggest that carbon was derived from a source with slightly depleted ${ }^{13} \mathrm{C}$, which seems to be partially related to microbial degradation of organic matter with weak sulfate reduction rates typical of freshwater systems. The $\delta^{13} \mathrm{C}$ isotopic fractionation between water bodies and the atmosphere is quite sensitive to temperature changes (Wefer et al., 1999). Lower temperatures result in extensive fractionation, and cold surface waters tend to have high $\delta^{13} \mathrm{C}$ values. Simulations for the Late Permian annual mean sea surface temperatures performed by Kiehl and Shields (2005) reveal paleotemperatures ranging between $16^{\circ} \mathrm{C}$ and $24{ }^{\circ} \mathrm{C}$ for the Paraná Basin paleolatitudes. Therefore, the negative $\delta^{13} \mathrm{C}$ values of the concretions can also be related to a freshwater body with warm waters. Another possible interpretation for the negative $\delta^{13} \mathrm{C}$ values is the depletion of ${ }^{13} \mathrm{C}$ at the water-sediment interface due to water recirculation and mixing driven by well-recorded storm events in the Serrinha Member (Lavina, 1991; Rohn, 1994; Warren et al., 2008). Diagenetic processes, such as recrystallization during burial and a later influx of meteoric waters, may also have slightly affected the carbon isotopic signatures and resulted in more negative $\delta^{13} \mathrm{C}$ values. However, the plot of $\delta^{13} \mathrm{C}$ versus $\delta^{18} \mathrm{O}$ of all isotopic data (Fig. 9) does not reveal a clear covariance between the data, indicating that the original values are preserved and that the diagenetic alteration hypothesis can be refuted.

Research concerning the sedimentology and stable isotopes of distinct concretion-bearing Permian units of the southwestern Gondwana basins is an excellent opportunity to increase our knowledge about the early diagenetic fluid history of such basins. In the same way, studying early diagenetic concretions is important and has helped expand our understanding of the paleobiological and paleoenvironmental reconstructions of the Paraná Basin and its chrono-correlated units across southwestern Gondwana (see Bondioli et al., 2015).

\section{Conclusions}

Carbonate concretions and subsequent carbonate-sulfate fracture fillings were preserved in mudstones and very fine-grained sandstones of the Late Permian Serrinha Member, Rio do Rasto Formation, Paraná Basin. The mineralogical, geochemical and textural evidence combined with stable carbon and oxygen isotope analyses of such concretions provide additional insights into their origin and the Serrinha Member depositional setting.

The non-deformed internal structure during the early growth, the decreasing proportion of carbonate cement relative to detrital grains toward the concretion edges, the well-preserved cardhouse fabric and the core-to-rim isotopic variations support an early diagenetic origin for these structures. Micrite-microspar cementation occurred at an earlier stage, prior to significant compaction; septarian fracturing occurred during rapid burial and localized overpressuring, as indicated by the presence of neo-formed barite crystals. The early authigenic carbonatecemented matrix may have helped maintain a closed system in carbonate concretions that prevented further chemical reactions with pore waters from the host sediments. The depleted oxygen isotope composition of the calcite cement and fracture fillings certainly is strong evidence of a freshwater origin for these concretions, indicating an early diagenesis with important effects from meteoric and freshwater pore fluids. According to paleogeographic reconstructions, sedimentological data and the isotopic data presented here, we are able to argue that the Paraná Basin likely had limited or no connections to the Panthalassa Ocean during the deposition of the Serrinha Member and that this basin was covered by a large and shallow freshwater body that was probably interconnected and extended to the chrono-correlated Falklands/ Malvinas Islands and the Karoo Basin. The negative $\delta^{13} \mathrm{C}$ values indicate low rates of primary productivity in the Serrinha Member epicontinental, warm, freshwater body.

Table 2

Lithologies and depositional environments from Late Permian units of the major Paleozoic basins in southern South America.

\begin{tabular}{|c|c|c|c|c|}
\hline Basin & Unit & Lithologies & Depositional environment & References \\
\hline Karoo Basin & Fort Brown Fm. & Mudstone, sandstone and siltstone & Prodelta & Johnson (1976) \\
\hline Malvinas/Falkland Islands & $\begin{array}{l}\text { Brenton Loch Fm. } \\
\text { Saladero Mb }\end{array}$ & $\begin{array}{l}\text { Rhythmic sandstones, siltstones and } \\
\text { mudstones }\end{array}$ & $\begin{array}{l}\text { Non-marine, lacustrine, episodic deposition } \\
\text { of prodeltaic hyperpycnal flow }\end{array}$ & Simões et al. (2012) \\
\hline Claromecó Basin & Tunas Fm. & Sandstones, mudstones and tuffs & Shallow marine at the base to fluvial at the top & Harrington (1980) \\
\hline Paraná Basin & $\begin{array}{l}\text { Rio do Rasto Fm. } \\
\text { Serrinha Mb. }\end{array}$ & $\begin{array}{l}\text { Mudstones and fine-grained } \\
\text { sandstones }\end{array}$ & $\begin{array}{l}\text { Shallow lakes, sometimes influenced by } \\
\text { storm waves or by fluvial incursions }\end{array}$ & $\begin{array}{l}\text { Rohn (1994), Holz et al. (2010), } \\
\text { Warren et al. (2008) }\end{array}$ \\
\hline \multirow[t]{3}{*}{ Paganzo Basin } & Talampaya Fm. (base) & Conglomerates, breccias and sandstones & Alluvial fans and braided rivers & Limarino et al. (2013) \\
\hline & $\begin{array}{l}\text { Talampaya Fm. } \\
\text { (middle) }\end{array}$ & Sandstones & $\begin{array}{l}\text { Braided ephemeral fluvial systems and } \\
\text { alternating eolian-fluvial }\end{array}$ & Limarino et al. (2013) \\
\hline & Talampaya Fm. (top) & Mudstones, evaporites and sandstones & Playa-lake and eolian & Limarino et al. (2013) \\
\hline Titicaca Basin & Chutani Fm. & $\begin{array}{l}\text { Silty dolostone, mudstone, marl, } \\
\text { fine-grained sandstone and } \\
\text { volcaniclastic sandstone }\end{array}$ & $\begin{array}{l}\text { Semiarid tidal flat with mixed carbonatic } \\
\text { and siliciclastic deposition }\end{array}$ & Vieira et al. (2004) \\
\hline
\end{tabular}


Table 3

Chemical compositions of matrix cements and septarian fractures.

\begin{tabular}{|c|c|c|c|c|c|c|c|c|c|c|c|c|c|c|c|c|c|c|}
\hline & $\begin{array}{l}\text { C } \\
\text { wt. \% }\end{array}$ & $\begin{array}{l}\text { O } \\
\text { wt. \% }\end{array}$ & $\begin{array}{l}\mathrm{Na} \\
\text { wt. \% }\end{array}$ & $\begin{array}{l}\mathrm{Mg} \\
\text { wt. \% }\end{array}$ & $\begin{array}{l}\text { Al } \\
\text { wt. \% }\end{array}$ & $\begin{array}{l}\text { Si } \\
\text { wt. \% }\end{array}$ & $\begin{array}{l}\text { P } \\
\text { wt. \% }\end{array}$ & $\begin{array}{l}\text { S } \\
\text { wt. \% }\end{array}$ & $\begin{array}{l}\text { K } \\
\text { wt. \% }\end{array}$ & $\begin{array}{l}\text { Ca } \\
\text { wt. \% }\end{array}$ & $\begin{array}{l}\text { Ti } \\
\text { wt. \% }\end{array}$ & $\begin{array}{l}\text { Mn } \\
\text { wt. \% }\end{array}$ & $\begin{array}{l}\text { Fe } \\
\text { wt. \% }\end{array}$ & $\begin{array}{l}\text { Ba } \\
\text { wt. \% }\end{array}$ & $\begin{array}{l}\text { Total } \\
\text { wt. \% }\end{array}$ & $\begin{array}{l}\mathrm{Mg} \\
\text { atomic \% }\end{array}$ & $\begin{array}{l}\mathrm{Ca} \\
\text { atomic \% }\end{array}$ & $\begin{array}{l}\mathrm{Mg} / \mathrm{Ca} \\
\text { molar }\end{array}$ \\
\hline \multicolumn{19}{|l|}{ Matrix } \\
\hline PC01-01 & - & 62.35 & - & 3.30 & 2.51 & 13.20 & - & 0.27 & 0.68 & 11.10 & 0.20 & 0.37 & 3.23 & - & 97.21 & 2.68 & 5.48 & 0.49 \\
\hline PC01-05 & 13.06 & 51.34 & - & 7.07 & 0.28 & 1.21 & - & 0.07 & - & 21.53 & - & 3.67 & 1.49 & 0.28 & 100.00 & 5.51 & 10.18 & 0.54 \\
\hline PC01-06 & 18.61 & 47.01 & 0.83 & 3.00 & 3.72 & 12.09 & 0.25 & 0.06 & - & 8.28 & - & 0.28 & 3.57 & 0.39 & 98.09 & 2.22 & 3.72 & 0.60 \\
\hline PC01-07 & 16.61 & 49.07 & 0.18 & 1.62 & 8.51 & 13.06 & 0.47 & 0.07 & 2.61 & 4.87 & - & 0.21 & 2.21 & 0.50 & 99.99 & 1.20 & 2.19 & 0.55 \\
\hline PC01-13 & 16.68 & 48.32 & 0.19 & 1.66 & 4.13 & 17.30 & 0.26 & 0.06 & 4.82 & 4.77 & - & - & 1.30 & 0.33 & 99.82 & 1.23 & 2.15 & 0.57 \\
\hline PC01-14 & 14.25 & 52.16 & - & 6.18 & 0.26 & 1.52 & - & 0.08 & - & 19.86 & - & 3.71 & 1.54 & 0.44 & 100.00 & 4.74 & 9.24 & 0.51 \\
\hline PC01-17 & 12.65 & 53.33 & - & 1.81 & 0.83 & 18.95 & 0.20 & 0.07 & 0.27 & 4.62 & 0.25 & 0.22 & 6.59 & 0.20 & 99.99 & 1.37 & 2.13 & 0.64 \\
\hline PC01-18 & 9.82 & 42.92 & - & 2.39 & 1.21 & 6.68 & 0.23 & 0.10 & 0.34 & 6.51 & 0.65 & 0.36 & 28.44 & 0.36 & 100.01 & 2.14 & 3.53 & 0.61 \\
\hline PC01-19 & 16.63 & 40.02 & - & 2.64 & 1.69 & 6.92 & 0.29 & 0.21 & 0.41 & 6.68 & 0.37 & 0.37 & 23.18 & 0.46 & 99.87 & 2.20 & 3.38 & 0.65 \\
\hline \multicolumn{19}{|l|}{ Septarias } \\
\hline PC01-08 & 27.23 & 48.32 & 0.19 & 2.06 & 6.75 & 8.48 & 0.07 & 0.05 & 0.15 & 5.49 & - & 0.26 & 0.79 & 0.15 & 99.99 & 1.39 & 2.25 & 0.62 \\
\hline PC01-09 & 17.73 & 48.48 & - & 1.44 & 0.54 & 26.17 & 0.17 & 0.04 & 0.16 & 4.09 & - & 0.24 & 0.81 & 0.13 & 100.00 & 1.05 & 1.80 & 0.58 \\
\hline PC01-10 & 17.64 & 51.81 & - & 1.65 & 0.32 & 22.55 & 0.10 & 0.08 & 0.06 & 4.73 & - & 0.27 & 0.78 & - & 99.99 & 1.18 & 2.06 & 0.57 \\
\hline PC01-11 & 19.47 & 51.16 & 0.13 & 1.48 & 0.35 & 21.66 & 0.10 & 0.07 & 0.07 & 4.08 & - & 0.27 & 0.98 & 0.19 & 100.01 & 1.05 & 1.76 & 0.60 \\
\hline PC01-15 & 17.80 & 47.93 & - & 6.18 & 0.49 & 2.65 & 0.05 & 0.35 & 0.11 & 17.87 & - & 3.17 & 1.68 & 1.71 & 99.99 & 4.70 & 8.25 & 0.57 \\
\hline PC01-16 & 20.07 & 49.83 & - & 6.71 & 0.53 & 2.66 & 0.06 & 0.07 & 0.10 & 17.36 & - & 1.16 & 1.12 & 0.30 & 99.97 & 4.88 & 7.65 & 0.64 \\
\hline
\end{tabular}

\section{Acknowledgments}

The authors wish to thank the Conselho Nacional de Desenvolvimento Científico e Tecnológico (CNPq, Brazil), process 142202/2013-4, for financial support and the University of São Paulo for institutional support. L.A. thanks Eduardo Guadagnin and Henrique Frasson for their help during the fieldwork, and R.M. thanks CNPq for the scholarship (Proc. 300423/ 82-9). The authors greatly acknowledge the thorough comments and suggestions made up by the reviewer John S. Compton and the editor Brian Jones, which contributed substantially to improve the original versions of the manuscript.

\section{References}

Abdel-Wahab, A., McBride, E.F., 2001. Origin of giant calcite-cemented concretions, Temple Member, Qasr El Sagha Formation (Eocene), Faiyum Depression, Egypt. Journal of Sedimentary Research 71, 70-81.

Araújo, L.M., Trigüis, J.A., Cerqueira, J.R., Freitas, L.C.S., 2000. The atypical Permian petroleum system of the Paraná Basin, Brasil. In: Melo, M.R., Katz, B.J. (Eds.), Petroleum Systems of South Atlantic Margin. AAPG Memoir 73, pp. 377-402.

Armstrong, H.A., Brasier, M.D., 2005. Microfossil, stable isotopes and ocean-atmosphere history. Microfossils, 2nd ed. 4. Blackwell Publishing, Malden, USA, pp. 25-34.

Astin, T.R., 1986. Septarian crack formation in carbonate concretions from shales and mudstones. Clay Minerals 21, 617-631.

Bayon, G., Pierre, C., Etoubleau, J., Voisset, M., Cauquil, E., Marsset, T., Sultan, N., Le Drezen, E., Fouquet, Y., 2007. $\mathrm{Sr} / \mathrm{Ca}$ and $\mathrm{Mg} / \mathrm{Ca}$ ratios in Niger Delta sediments: Implications for authigenic carbonate genesis in cold seep environments. Mar. Geol. 241, 93-109.

Benton, M.J., Newell, A.J., 2013. Impacts of global warming on Permo-Triassic terrestrial ecosystems. Gondwana Research 25, 1308-1337.

Bondioli, J.G., Matos, S.A., Warren, L.V., Assine, M.L., Riccomini, C., Simões, M.G., 2015. The interplay between event and background sedimentation and the origin of fossil-rich carbonate concretions: a case study in Permian rocks of the Paraná Basin, Brazil. Lethaia 45, 1-18.

Bréhéret, J.G., Brumsack, H.-J., 2000. Barite concretions as evidence of pauses in sedimentation in the Marnes Bleues Formation of the Vocontian Basin (SE France). Sedimentary Geology 130, 205-228.

Cagliari, J., Lavina, E.L.C., Philipp, R.P., Tognoli, F.M.W., Basei, M.A.S., Faccini, U.F., 2014 New Sakmarian ages for the Rio Bonito formation (Paraná Basin, southern Brazil) based on LA-ICP-MS U-Pb radiometric dating of zircons crystals. Journal of South American Earth Sciences 56, 256-277.

Compton, J.S., 1988. Degree of supersaturation and precipitation of organogenic dolomite. Geology 16, 318-321.

Curtis, C.D., Coleman, M.L., Love, L.G., 1986. Pore water evolution during sediment burial from isotopic and mineral chemistry of calcite, dolomite and siderite concretions. Geochimica et Cosmochimica Acta 50, 2321-2334.

Curtis, C.D., Coleman, M.L., 1986. Controls on the precipitation of early diagenetic calcite, dolomite and siderite concretions in complex depositional sequences. In: Gautier, D.L. (Ed.), Roles of Organic Matter in Sedimentary Diagenesis. Soc. Econ. Paleontol. Mineral. Spec. Pub. 38, pp. 23-33.

Dale, A., John, C.M., Mozley, P.S., Smalley, P.C., Muggeridge, A.H., 2014. Time-capsule concretions: unlocking burial diagenetic processes in the Mancos Shale using carbonate clumped isotopes. Earth and Planetary Science Letters 394, 30-37.

Dong, J., Zhanga, S., Jiangc, G., Li, H., Gaob, R., 2013. Greigite from carbonate concretions of the Ediacaran Doushantuo Formation in South China and its environmental implications. Precambrian Research 225, 77-85.
Froelich, P.N., Klinkhammer, G.P., Bender, M.L., Luedtke, N.A., Heath, G.R., Cullen, D., Daupin, P., Hammond, B., Maynard, V., 1979. Early oxidation of organic matter in pelagic sediments of the eastern equatorial Atlantic: sub-oxic diagenesis. Geochimica et Cosmochimica Acta 43, 1075-1090.

Gama Jr., E., 1979. A sedimentação do Grupo Passa Dois (exclusive Formação Irati), um modelo geomórfico. Revista Brasileira de Geociencias 9 (1), 1-16.

Gordon Jr., M., 1947. Classificação das formações gonduânicas do Paraná, Santa Catarina e Rio Grande do Sul. Notas preliminares e estudos, DNPM, DGM v. 38 20p.

Gohrbandt, K.H.A., 1992. Paleozoic paleogeographic and depositional developments on the central proto-Pacific margin of Gondwana: their importance to hydrocarbon accumulation. Journal of South American Earth Sciences 6, 268-287.

Goldberg, T., Mazumdar, A., Strauss, H., Shields, G., 2006. Insights from stable S and O isotopes into biogeochemical processes and genesis of Lower Cambrian barite-pyrite concretions of South China. Organic Geochemistry 37, 1278-1288.

Guerra-Sommer, M., Cazzulo-Klepzig, M., Formoso, M.L.L., Menegat, R., Basei, M.A.S., 2005 New radiometric data from ash fall rocks in Candiota coal-bearing strata and the palynostratigraphic framework in southern Paraná Basin (Brazil). In: Pankhurst, R.J., Veiga, G.D. (Eds.), Abstracts. Gondwana vol. 12, p. 89 (Mendoza, Argentina).

Guerra-Sommer, M., Cazzulo-Klepzig, M., Formoso, M.L.L., Menegat, R., Mendonça Filho J.G., 2008a. U-Pb dating of tonstein layers from a coal succession of southern Paraná Basin (Brazil): a new geological approach. Gondwana Research 14, 474-482.

Guerra-Sommer, M., Cazzulo-Klepzig, M., Menegat, R., Formoso, M.L.L., Basei, M.A.S., Barbosa, E.G., Simas, M.W., 2008b. Geochronological data from Faxinal coal succession in southern Brazil. Preliminary approach combining geochronological U/Pb age and palynostratigraphy. Journal of South American Earth Sciences 25, 246-256.

Harrington, H.J., 1980. Sierras Australes de la provincia de Buenos Aires. Segundo Simposio de Geología Regional Argentina vol. 2. Academia Nacional de Ciencias, Córdoba, pp. 967-983.

Hoareau, G., Odonne, F., Debroas, E.-J., Maillard, A., Monnin, C., Callot, P., 2009. Dolomitic concretions in the Eocene Sobrarbe delta (Spanish Pyrenees): fluid circulation above a submarine slide scar infilling. Marine and Petroleum Geology 26, 724-737.

Hoefs, J., 2004. Stable Isotope in Geochemistry. 5th ed. Springer- Verlag, Germany (244 pp.).

Holz, M., França, A.B., Souza, P.A., Iannuzzi, R., Rohn, R., 2010. A stratigraphic chart of the Late Carboniferous/Permian succession of the eastern border of the Paraná Basin, Brazil, South America. Journal of South American Earth Sciences 29, 381-399.

Hudson, J.D., Coleman, M.L., Barreiro, B.A., Hollingworth, N.T.J., 2001. Septarian concretions from the Oxford Clay (Jurassic, England, UK): involvement of original marine and multiple external pore fluids. Sedimentology 48, 507-531.

Irwin, H., Curtis, C.D., Coleman, M., 1977. Isotopic evidence for source of diagenetic carbonates formed during burial of organic rich sediments. Nature 269, 209-213.

Johnson, M.R., 1976. Stratigraphy and Sedimentology of the Cape and Karoo Sequences in the Eastern Cape Province (PhD Thesis), Rhodes University, South Africa (366 pp.).

Kiehl, J.T., Shields, C.A., 2005. Climate simulation of the latest Permian: implications for mass extinction. Geology 33, 757-760.

Lavina, E.L., 1991. Geologia sedimentar e paleogeografia do Neopermiano e Eotriássico (intervalo Kazaniano-Citiano) da Bacia do Paraná (Tese de Doutoramento), Instituto de Geociências, Universidade Federal do Rio Grande do Sul, Porto Alegre (332 pp.).

Limarino, C.O., Césari, S.N., Spalletti, L.A., Taboada, A.C., Isbell, J.L., Geuna, S., Gulbranson, E.L., 2013. A paleoclimatic review of southern South America during the late Paleozoic: a record from icehouse to extreme greenhouse conditions. Gondwana Research 25, 1396-1421.

Lowenstein, T.K., Timofeeff, M.N., Brennan, S.T., Hardie, L.A., Demicco, R.V., Lowenstein, T.K., Timofeeff, M.N., Brennan, S.T., Hardie, L.A., Demicco, R.V., 2001. Oscillations in Phanerozoic seawater chemistry: Evidence from fluid inclusions. Science v. 294 1086-1088. http://dx.doi.org/10.1126/science.1064280.

Magaritz, M., Goldenberg, L., Kafri, U., Arad, A., 1980. Dolomite formation in the seawater freshwater interface. Nature (London) 287, 622-624. 
Mahboubi, A., Moussavi-Harami, R., Collins, L.B., Muhling, J.R., 2010. Petrography and geochemical signatures in crack filling calcite sequences in septarian concretions, Sanganeh Formation, Kopet-Dagh Basin, NE Iran. Journal of Applied Sciences 1-9.

Matos, S.L.F., Yamamoto, J.K., Riccomini, C., Hachiro, J., Tassinari, C.C.G., 2001. Absolute dating of Permian ash-fall in the Rio Bonito Formation, Paraná Basin, Brazil. Gondwana Research 4, 421-426.

McBride, E.F., Millliken, K.L., Cavazza, W., Cibin Fontana, D., Picard, M.D., Zuffa, G.G., 1995 Heterogeneous distribution of calcite cement at the outcrop scale in Tertiary sandstones, northern Apennines Italy. American Association of Petroleum Geologists Bulletin 79, 1044-1063.

McBride, E.F., Picard, M.D., Milliken, K., 2003. Calcite-cemented concretions in Cretaceous sandstones Wyoming and Utah, U.S.A. Journal of Sedimentary Petrology 73, 462-483.

Milani, E.J., 1997. Evolução tectono-estratigráfica da Bacia do Paraná e seu relacionamento com a geodinâmica fanerozóica do Gondwana sul-ocidental. Instituto de Geociências, Universidade Federal do Rio Grande do Sul (Doctoral Thesis, 255 pp.).

Milani, E.J., Ramos, V.A., 1998. Orogenias Paleozóicas no domínio sul-ocidental do Gondwana e os ciclos de subsidência da Bacia do Paraná. Revista Brasileira de Geociencias $28,473-484$.

Milani, E.J., Zalán, P.Y., 1999. An outline of the geology and the petroleum system of the Paleozoic interior basin of South America. Episodes 22 (3), 199-205.

Morad, S., De Ros, L.F., Al-Aasm, I.S., 1996. Origin of low d ${ }^{18}$ O, pre-compactional ferroan carbonates in the marine Sto Formation (Middle Jurassic), offshore NW Norway. Marine and Petroleum Geology 13, 263-276.

Mori, A.L.O., de Souza, P.A., Marques, J.C., da Cunha Lopes, R., 2012. A new U-Pb zircon age dating and palynological data from a Lower Permian section of the southernmost Paraná Basin, Brazil: biochronostratigraphical and geochronological implications for Gondwanan correlations. Gondwana Research 21, 654-669.

Mozley, P.S., 1996. The internal structure of carbonate concretions in mudrocks: a critical evaluation of the conventional concentric model of concretion growth. Sedimentary Geology 103, 85-91.

Mozley, P.S., Burns, S.J., 1993. Oxygen and carbon isotopic composition of marine carbonate concretions: an overview. Journal of Sedimentary Petrology 63, 73-83.

Mozley, P.S., Davis, J.M., 2005. Internal structure and mode of growth of elongate calcite concretions: evidence for small-scale, microbially induced, chemical heterogeneity inground water. Geological Society of America Bulletin 117 (11), 1400.

Pirrie, D., Marshall, J.D., 1991. Field relationships and stable isotope geochemistry of concretions from James Ross Island, Antarctica. Sedimentary Geology 71, 137-150.

Pratt, B.R., 2001. Septarian concretions: internal cracking caused by synsedimentary earthquakes. Sedimentology 48, 189-213.

Rabassa, J., 2006. Unusual morphology of calcareous concretions in glaciolacustrine sediments, late Pleistocene, Lago Ghio, Patagonia, Argentina - a short note. Quaternary International 147, 113-115.

Raiswell, R., Bottrell, S.H., Dean, S.P., Marshall, J.D., Carr, A., Hatfield, D., 2002. Isotopic constraints on growth conditions of multiphase calcite-pyrite-barite concretions in Carboniferous mudstones. Sedimentology 49, 237-254.

Raiswell, R., 1971. The growth of Cambrian and Liassic concretions. Sedimentology 17 147-171.

Ramos, V.A., 1984. Patagonia: ¿Un continente paleozoico a la deriva? $9^{\circ}$ Congreso Geológico Argentino (Bariloche). Actas vol. 2, pp. 311-325

Ramos, V.A., 1986. Tectonostratigraphy, as applied to analysis of South African Phanerozoic Basins by H. de la R. Winter, discussion. Transactions Geological Society of South Africa 87 (2), 169-179.

Ramos, V.A., 2008. Patagonia: a paleozoic continent adrift? Journal of South American Earth Sciences 26, 235-251.

Retallack, G.J., 1995. Permian-Triassic life crisis on land. Science 267, 77-80.

Rocha-Campos, A.C., Basei, M.A.S., Nutman, A.P., Santos, P.R.dos., 2006. SHRIMP U-Pb Zircon geochronological calibration of the Late Paleozoic Supersequence, Paraná Basin, Brazil. In: Milani, E.J., Pereira, E., Castro, J., Della Fávera, J.C., Almeida, L.F.B., Bergamaschi, S. (Eds.), $5^{\circ}$ South American Symposium on Isotopic Geology (Punta del Este), Uruguay, Short Papers, pp. 298-301.

Rocha-Campos, A.C., Basei, A.C., Nutman, M.A.S., Santos, P.R., 2007. Shrimp U-Pb zircon ages of the late Paleozoic sedimentary sequence, Paraná Basin, Brasil. Simpósio sobre Cronoestratigrafia da Bacia do Paraná. Armação de Búzios. Boletim de Resumos vol. 4. Sociedade Brasileira de Paleontologia, p. 33.
Rodrigues, G.B., Fauth, G., 2013. Isótopos estváveis de carbono e oxigênio em ostracodes do Cretáceo: metodologias, aplicações e desafios. Terrae Didatica 9, 34-49.

Rohn, R., 1994. Evolução ambiental da Bacia do Paraná durante o Neopermiano no leste de Santa Catarina e do Paraná. Programa de Pós-graduação em Geologia Sedimentar. Universidade de São Paulo (Doctoral Thesis, 386 pp.).

Roscher, M., Stordal, F., Svensen, H., 2011. The effect of global warming and global cooling on the distribution of the latest Permian climate zones. Palaeogeography, Palaeoclimatology, Palaeoecology 309, 186-200.

Santos, R.V., Souza, P.A., de Alvarenga, C.J.S., Dantas, E.L., Pimentel, M.M., de Oliveira, C.G., de Araújo, L.M., 2006. Shrimp U-Pb zircon dating and palynology of bentonitic layers from the Permian Irati Formation, Paraná Basin, Brazil. Gondwana Research 9, 456-463.

Schneider, R.L., Mühlmann, H., Tommasi, E., Medeiros, R.A., Daemon, R.F., Nogueira, A.A., 1974. Revisão estratigráfica da Bacia do Paraná. Congresso Brasileiro de Geologia, XXVIII, 1974, Porto Alegre. Anais, Sociedade Brasileira de Geologia, Porto Alegre vol. 1, pp. 41-66.

Schobbenhaus C., Campos D.A., Derze G.R., Asmus H.E. 1984. Geologia do Brasil. Texto Explicativo do Mapa Geológico do Brasil e da Área Oceânica Adjacente incluindo Depósitos Minerais. Escala 1:2.500.000. Brasília, DNPM-MME, 501p.

Seilacher, A., 2001. Concretion morphologies reflecting diagenetic and epigenetic pathways. Sedimentary Geology 143, 41-57.

Selles-Martinez, J., 1996. Concretions morphology, classification and genesis. Earth Sciences Review 41, 177-210.

Simões, M.G., Quaglio, F., Warren, L.V., Anelli, L.E., Stone, P., Riccomini, C., Grohmann, C.H., Chamani, M.A.C., 2012. Permian non-marine bivalves of the Falkland Islands and their paleoenviromental significance. Alcheringa 37, 1-13.

Vieira, C., Iannuzzi, R., Guerra-Sommer, M., DíazMartinez, E., Grader, G., 2004. Permian plants from the Chutani Formation (Titicaca Group, Northern Altiplano of Bolivia): I. genera Pecopteris and Asterotheca. An Acad Bras Cienc 76, 117-128.

Veevers, J.J., Powell, C.A., 1987. Late Paleozoic glacial episodes in Gondwanaland reflected in transgressive-regressive depositional sequences in Euroamerica. Geological Society of America Bulletin 98, 475-487.

Visser, J.N.J., 1995. Post-glacial Permian stratigraphy and geography of southern and central Africa: boundary conditions for climatic modelling. Palaeogeography, Palaeoclimatology, Palaeoecology 118, 213-243.

Vochten, R.F.C. Geys, J.F. 1974. Pyrite and calcite in septarian concretions from the Rupelian clay (Oligocene) at Rumst (Antwerpen, Belgium) and their geochemical composition. Chemical Geology 14, 123-134.

Wanas, H.A., 2008. Calcite-cemented concretions in shallow marine and fluvial sandstones of the Birket Qarun Formation (Late Eocene), El-Faiyum depression, Egypt: field, petrographic and geochemical studies: implications for formation conditions. Sedimentary Geology 212, 40-48.

Warren, L.V., Almeida, R.P., Hachiro, J., Machado, R., Roldan, L.F., Steiner, S.S., Chamani, M.A.C., 2008. Evolução sedimentar da Formação Rio do Rasto (Permo-Triássico da Bacia do Paraná) na porção centro sul do estado de Santa Catarina, Brasil. Revista Brasileira de Geociencias 38, 213-227.

Wefer, G., Berger, W.H., Bijma, J., Fischer, G., 1999. Clues to ocean history: a brief overview of proxies. In: Fischer, G., Wefer, G. (Eds.), Use of Proxies in Paleoceanography: Examples From de South Atlantic. Springer, pp. 1-68.

Wilkinson, M., 1993. Concretions of the Valtos Sandstone Formation of Skye: geochemical and palaeo-hydrology. Journal of the Geological Society of London 150, 57-66.

Woo, K.S., Khim, B.K., 2006. Stable oxygen and carbon isotopes of carbonate concretions of the Miocene Yeonil Group in the Pohang Basin, Korea: types of concretions and formation conditions. Sedimentary Geology 183, 15-30.

Yemane, K., 1993. Contribution of Late Permian palaeogeography in maintaining a temperate climate in Gondwana. Nature 361, 51-54

Yemane, K., Kelts, K., 1996. Isotopic geochemistry of Upper Permian early diagenetic calcite concretions. Implications for Late Permian waters and surface temperatures in continental Gondwana. Paleoecology, Paleogeography, Paleoclimatology 125, 51-73.

Ziegler, A.M., Hulver, M.L., Rowley, D.B., 1997. Permian world topography and climate. In: Martini, I.P. (Ed.), Late Glacial and Postglacial Environmental Changes: Quaternary, Carboniferous-Permian and Proterozoic. Oxford University Press, Oxford, pp. 111-146. 